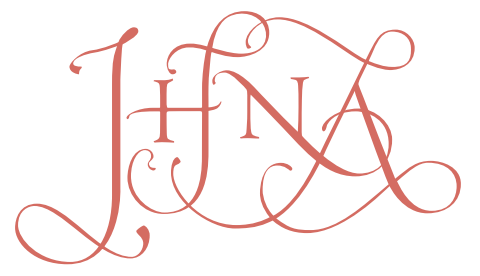

JOURNAL OF HISTORIANS OF NETHERLANDISH ART

Volume 8, Issue 2 (Summer 2016)

European Research Council

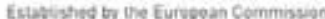

Supporting top researchers from anywhere in the world

\title{
The Sensible Natures: Allart Van Everdingen and the Tradition of Sublime Landscape in Seventeenth-Century Dutch Painting
}

Jan Blanc

jan.blanc@unige.ch

Recommended Citation:

Jan Blanc, "Sensible Natures: Allart Van Everdingen and the Tradition of Sublime Landscape in Seventeenth-Century Dutch Painting," JHNA 8:2 (Summer 2016), DOI: 10.5092/jhna.2016.8.2.4 Available at https://jhna.org/articles/allart-van-everdingen-tradition-sublime-landscape-seventeenth-century-dutch-painting/

Published by Historians of Netherlandish Art: https://hnanews.org/ Republication Guidelines: https://jhna.org/republication-guidelines/

Notes: This PDF is provided for reference purposes only and may not contain all the functionality or features of the original, online publication. This PDF provides paragraph numbers as well as page numbers for citation purposes.

ISSN: 1949-9833 


\section{SENSIBLE NATURES: ALLART VAN EVERDINGEN AND THE TRADITION OF SUBLIME LANDSCAPE IN SEVENTEENTH-CENTURY} DUTCH PAINTINGS

\section{Jan Blanc}

This article seeks to understand if and under which conditions the antique theories of the sublime could have been important in the artistic practice of the Dutch landscape painter Allart van Everdingen. His social and familial milieu was learned, yet nothing, in what we know of the culture of Allart van Everdingen, seems to indicate that the painter was able to have direct access to the primary or secondary sources on the sublime. Longinus or Lucretius probably did not mean anything for him. Surely Allart van Everdingen's sublime culture was built on images more than on texts, whether these images were real (works of art that he was able to see and study) or imaginary (missing or fictitious works that he could have known through the artistic literature). Rather than of a sublime culture, moreover, it would be better to speak here of a sublime sensitivity, fueled not only by the arts but also by the everyday life of the seventeenth-century Dutch men and women who, faced with the sometimes dangerous spectacle of Nature, often used the categories of sublime rhetoric or literature to describe their life experiences. More than landscapes, Allart van Everdingen's paintings are first - and this remark could possibly be generalized to other Dutch painters of the Golden Age - personal and general experiences translated into images, which have been all the more powerful as they echoed categories and emotions largely shared by their beholders. DOI: 10.5092/jhna.2016.8.2.4

It is far from easy to prove that theories of the sublime may have had a direct, or even an indirect, impact on the productions of a painter such as the seventeenth-century Dutch landscape painter Allart van Everdingen. Recently, this kind of inquiry, regarding the relations between philosophical, rhetorical, or aesthetic theories and artistic practices, has been applied to several artists. Gustavo Costa suggested that the circulation of Longinus's treatise on the sublime in the Farnesian milieu, at the end of the fifteenth century and the beginning of the sixteenth, could have played an essential role in Michelangelo's art, especially in relation to the notion of terribilità, linked with the Greek notion of deinos. ${ }^{1}$ In a more recent book, Clelia Nau tried to establish that some of the landscapes painted by Nicolas Poussin could be better understood through the Longinian theory of the sublime. ${ }^{2}$ Yet in each of these studies it is possible to identify some difficulties. As Eugenio Refini wrote, "Michelangelo's possible acquaintance with Longinus [does] not reveal a conscious knowledge of Longinus' categories," ${ }^{3}$ regarding especially the notion of sublime and terrible beauty. Clelia Nau's book poses the same kind of problem. Her close-reading demonstration is highly learned and subtle in distinguishing the circulation and translations of the Longinian theories of the sublime in and around Poussin's milieu. Nevertheless, it is difficult to know if these ideas were, for Poussin and his friends, not just ordinary commonplaces, known through a great 
number of reinterpretations and without any pertinent significance for the artist. Additionally, the method used by Clelia Nau is highly problematic. It begins with a very precise reading of the written, literary, philosophical, and rhetorical sources, before trying to find in Poussin's paintings traces of these theories, without ever posing the question of the specifically pictorial and artistic conventions that can also explain many of the painter's iconographical and stylistic choices.

Would it be possible to trace the importance of sublime ideas in the works of the painters without being compelled to link these ideas with written sources, literary concepts, and poetical notions? If we want to demonstrate that real and convincing relations exist between the theories of the sublime and the practices of a painter, it is necessary to fulfill some conditions. It is a requirement, for example, to prove that the painter would have known and understood these theories. It is also crucial to identify and analyze visual evidence of this understanding within the works of this painter-this evidence should be iconographical and (if possible) formal and should not be explainable only through explicit artistic conventions. This article, devoted to seventeenth-century Dutch landscape painters and, especially, to Allart van Everdingen, will take up this challenge and try to understand if, and under which conditions, the antique theories of the sublime described in this volume could hold some importance in the artistic pratice of this artist. Specialized in and admired for the representation of Scandinavian landscapes, van Everdingen seems to have chosen to paint territories which, during the seventeenth century, were assimilated to wild spaces and located on the border of the civilized world. The visual characteristics of these exotic and wild sceneries defy the qualities and the properties of beauty, according to a theme very present in the sublime imaginary, especially in Longinus's treatise: "I would affirm with confidence that there is no tone so lofty as that of genuine passion, in its right place, when it bursts out in a wild gust of mad enthusiasm and as it were fills the speaker's words with frenzy." ${ }^{\text {I }}$ I will therefore scrutinize van Everdingen's potential knowledge of theories of the sublime, first through the artistic traditions of the European and Dutch landscape, and then viathe written sources of which van Everdingen may have been aware.

\section{Van Everdingen and His Possible Access to the Sublime Literature}

Allart van Everdingen was born in Alkmaar in 1621, the second son of Pieter Cornelisz, and died in 1675. The education and instruction of the male members of his family seem to have been of a good standard. ${ }^{6}$ His brother, Caesar van Everdingen, who was born four years earlier, was a famous history painter. ${ }^{7}$ A former pupil of the genre and history painter Jan van Bronchorst in Utrecht, ${ }^{8}$ Caesar was also a member of the Alkmaar guild in $1632,{ }^{9}$ before moving to Haarlem, where he joined the St. George Civic Guard Company $(1648)^{10}$ and the guild, serving as an officer between 1653 and $1656 .{ }^{11}$ In his oeuvre we can see traces of a rich literary culture, even if the chosen subjects are all very conventional. This is the case with his allegorical paintings for the Huis ten Bosch near The Hague: the Allegory of the Birth of Frederick Hendrik, the Four Muses and Pegasus on Mount Parnassus (fig. 1), and the Allegory of Marriage, with Venus, Juno, Jupiter and Ganymede and Putti with an Hourglass and the Monogram of Frederick Hendrik and Amalia van Solms are subtle allegorical and mythological propositions, certainly the more complex in Caesar's oeuvre, yet without any originality or complexity. ${ }^{12}$ Furthermore, we know that Constantijn Huygens, the former secretary of Frederik Hendrik, had conceived the program of the Oranjezaal, and not the painters. ${ }^{13}$ 


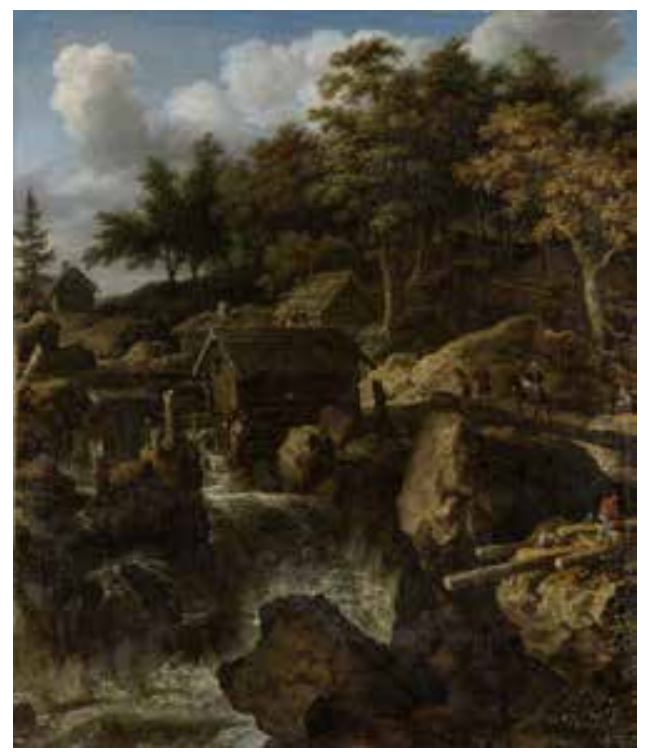

Fig. 1 Caesar van Everdingen, Four Muses and Pegasus on Mount Parnassus, ca. 1650, oil on canvas, $340 \times 230 \mathrm{~cm}$. The Hague, Huis ten Bosch Palace (artwork in the public domain)

Some other rare themes, allegorical and historical, can be identified in Caesar's oeuvre, even if, in each case, it is quite difficult to suppose that the painter could have been the inventor. In first place, we can cite the Portrait of the Steyn Family, also known as Diogenes Looking for an Honest Man (1652, The Hague, Maurithuis). ${ }^{14}$ Was Caesar van Everdingen responsible for the quite strange invention of this painting, based on the life of the philosopher Diogenes of Sinope, as recorded by Diogenes Laërtius? It seems to be more convincing to suppose that this collective portrait of the Steyn family was the original idea of the commissioner, Jacob Steyn. The same kind of relationship between the patron and the painter can certainly explain the infrequent subject of the Count Willem II Conferring the Charter on the Water Board of Rijnland in 1255 (1654, Leiden, Gemeenlandshuis), ${ }^{15}$ certainly conceived by the architect Pieter Post, who had devised the plan of the Gemeenlandshuis, called Swanenburg, at Halfweg, and its great hall, for which Caesar's painting was executed. ${ }^{16}$ And it is also possible to consider that the Lycurgus Demonstrating the Benefits of Education (ca. 1660-62, Alkmaar, Stedelijk Museum), the only known portrayal of this subject in a Dutch painting, taken from the Moralia by the Greek writer Plutarch, should be attributed to the artist, since this painting was a commission by the city of Alkmaar for the so-called Prinsenkamer in the town hall. ${ }^{17}$

Even if Allart van Everdingen's family counted some well-educated men, it appears to be challenging to find, in his landscapes or in the paintings of his brother, actual evidence of major involvement in Dutch scholarly culture. Could we find more clues in Allart van Everdingen's artistic milieu? On February 21, 1645, we know that he married Janneke Cornelisdr Brouwers in Haarlem. ${ }^{18}$ In October, he lived with his wife on Groote Houtstraat and joined the Reformed Church. ${ }^{19}$ He became a member of the Reformed Church in Haarlem on October 13, 1645, joined the Haarlem Guild of St. Luke in $1646,{ }^{20}$ and, along with his brother Caesar, enlisted in the St. George Civic Guard Company in $1648 .{ }^{21} \mathrm{He}$ stayed in the city until 1652, when he moved to Amsterdam, ${ }^{22}$ where he became a citizen on April 10, 1657, ${ }^{23}$ living at No. 4 Conincxstraat, then at Bantammerstraet. ${ }^{24}$

During this period, between 1645 and 1652, Haarlem knew one of its most flourishing artistic 
periods, dominated by the idea of the ennoblement of artistic practices. After the Guild of St. Luke's reorganization in 1631, stimulated by Cornelis Cornelisz. van Haerlem, and the creation of a specific guild for metalworkers in 1639, painters came to dominate the guild's administration and wanted to be considered as real and serious liberal artists. In 1649 Pieter Fransz. de Grebber, son of a famous painter and art dealer, Frans Pietersz. de Grebber, who served as Rubens's agent with Sir Dudley Carleton, the English ambassador to The Hague, published a one-page theoretical memento outlining eleven rules, ${ }^{25}$ which can be seen as a kind of manifesto for some of the Haarlem painters of the Oranjezaal, including Caesar van Everdingen, Salomon de Braij, or Pieter Soutman. ${ }^{26}$ Local historians, among them Theodorus Schrevelius (Harlemum, 1647), rector of the Latin School of Leiden, wrote historical and artistic descriptions of Haarlem in order to extol the virtues of the city and its contemporary artists. Membership in specific cultural institutions or associations could have enabled Allart van Everdingen to have an indirect access to some of Haarlem's literary and philosophical background, for example, De Wijngaartrancken (The Vine Branch), one of the city's three rederijkerskamers (rhetoricians' chambers), to which many Haarlem painters belonged.

Clearly his social background could have had an impact on Allart van Everdingen's paintings. Yet it is not necessarily obvious how the Dutch painter could have had access to the sublime literature. Among the most major theories of the sublime, it is not difficult to identify three different sources that could have been known by Allart van Everdingen: Pseudo-Longinus's Peri hypsous, Lucretius's De natura rerum, and some other rhetorical writings (especially Pseudo-Demetrius's Peri hermeneias and Hermogenes's Peri ideon). Nothing in the archival documentation gathered through the years ${ }^{27}$ proves that Allart van Everdingen could read and understand Latin or Greek. We must then concentrate our inquiry on books and writings in vernacular language.

8 We know that the concept of the sublime had been mainly forged in the treatise Peri hypsous, attributed to Longinus and probably written in the first century AD. This text was widely acknowledged only after Nicolas Boileau published a French translation, Traité du sublime, in 1674. ${ }^{28}$ Nevertheless, many manuscript copies had already circulated in Europe, especially during the sixteenth century, ${ }^{29}$ enabling Longinus's ideas to be known and discussed in Italy ${ }^{30}$ and France. ${ }^{31}$ Some Italian poets, such as Pietro Bembo, used Longinian categories ${ }^{32}$ even before Francesco Robortello first published the text in Italian in $1554 .{ }^{33}$ In 1635 , nearly forty years before the publication of the Traité du sublime, Leone Allacci produced a dense and precise commentary on Longinus's book, ${ }^{34}$ which probably played a significant role in Roman circles of this time. ${ }^{35}$ Ten years later, the first French translation of Longinus's treatise was written, probably in the entourage of Cardinal Mazarin. ${ }^{36}$

9 Allart van Everdingen probably never traveled in Italy, and it is improbable that he was able to read Italian, even if his great-grandfather, Caesar Boetus, had Italian roots. ${ }^{37}$ So what about the reception of Longinus's text in the northern part of Europe? In England, ${ }^{38}$ the poets George Chapman and John Milton quoted Longinus ${ }^{39}$ even before the first English translation of Longinus, by John Hall, appeared in $1652 .{ }^{40}$ Other authors, such as the art theoretician William Sanderson, explicitly refer to Longinus's ideas. ${ }^{41}$ Yet contrary to van Everdingen, these English writers understood the ancient languages and thus had direct access to Longinus's Greek text or one of its Latin translations. John Hall's translation seems to have been well received, since it is quoted as an 
authority in the Academy of Eloquence published by Thomas Blount in $1653 .{ }^{42}$ Nonetheless, and even if we suppose that Allart van Everdingen was able to read and understand a book written in English, this translation was published quite late in the artist's career: by 1652, van Everdingen had already traveled to Scandinavia and fixed the standard of his marine paintings, northern landscapes and waterfalls. The same problem arises as regards Lucretius's De natura rerum. ${ }^{43}$ Very well known by scholars and erudite readers in its original Latin version since its rediscovery in 1417 by Poggio Bracciolini, ${ }^{44}$ this poem was only been translated (or adapted) into French around $1650^{45}$ and into Dutch in $1710 .^{46}$

10 Since we know of no German translation of Longinus's Peri hypsous before the eighteenth centu$\mathrm{ry}^{47}$ (the first Dutch translation of Longinus' treatise was published in 1811), ${ }^{48}$ and because van Everdingen died in 1675, one year after Nicolas Boileau's French translation, it seems to be impossible that he could have had direct access to Longinus's book. Nonetheless, other more convincing avenues should be explored, beginning with first visual evidence.

\section{Van Everdingen and the Sublime Tradition in Dutch Landscape}

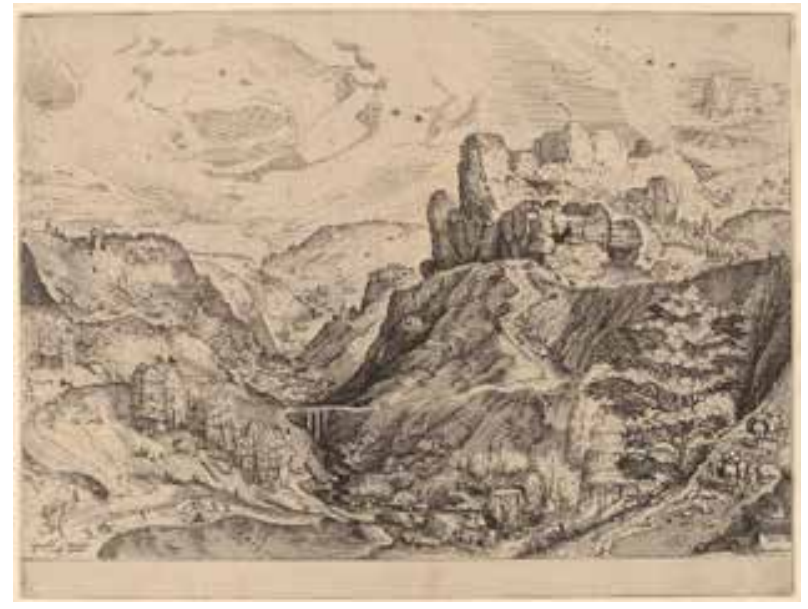

Fig. 2 Johannes and Lucas van Doetechum, after Pieter Bruegel the Elder, Alpine Landscape, ca. 1555-57, etching and engraving, $32.1 \times 42.7 \mathrm{~cm}$. Washington, D.C., National Gallery of Art, inv. no. 1964.8.411 (artwork in the public domain)

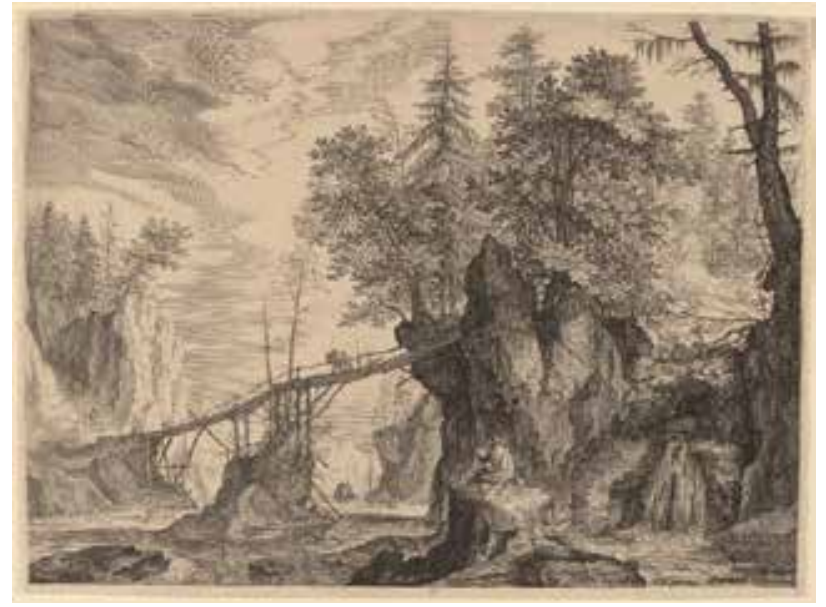

Fig. 3 Aegidius Sadeler II, after Roelant Savery, Draftsman on a Stone before a Bridge, ca. 1609, engraving, $22.5 \times 28 \mathrm{~cm}$. Washington, D.C., National Gallery of Art, inv. no. 1943.3.7619 (artwork in the public domain)

11 According to Arnold Houbraken, Allart van Everdingen had two masters: Roelandt Savery (1576-1639) in Utrecht, then Pieter Molyn (1595-1661) in Haarlem. ${ }^{49}$ Whereas the mechanical technique and the use of brownish tone characteristic of Pieter Molyn could have been of some importance for van Everdingen, the themes typical of Roelandt Savery probably had more significance for him. After he was invited to the court of Rudolf II, Roelandt Savery tried to present himself as a kind of artistic descendant of Pieter Bruegel the Elder (fig. 2), by promoting his direct imitation of nature (naer het leven) but also by showing his capacity of producing lively and powerful landscapes (fig. 3). His travel into the Tyrol, ca. 1606-7, can be understood as an attempt to emulate with the famous journey of Bruegel the Elder through the Alps on his way to and from Italy, between 1551 and around 1554, and during which, says Karel van Mander, he "swallowed all the mountains and rocks and spat them out again, after his return, onto his canvases and panels." ${ }^{0}$ 


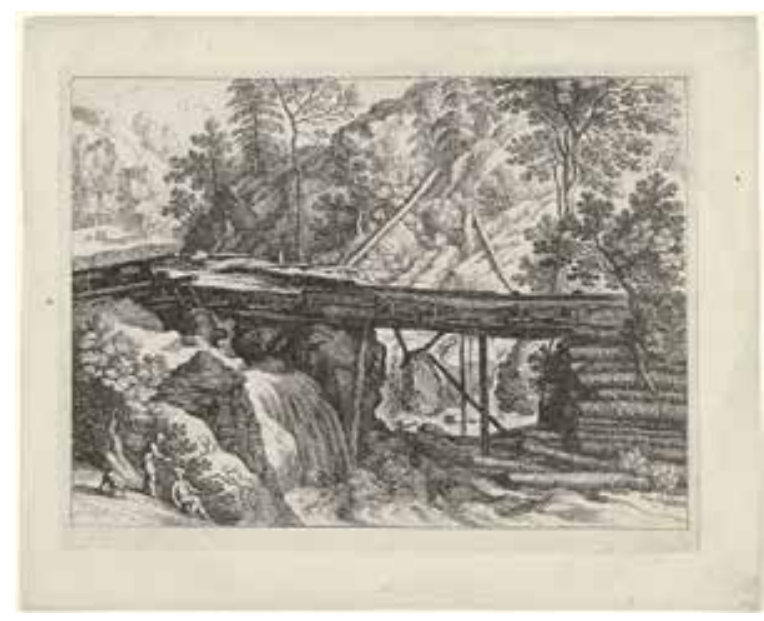

Fig. 4 Willem van Nieulandt II, after Paul Bril, A Wooden Bridge over a Mountain Stream, ca. 1594-1635, etching and engraving, 23.5 × 31.1 cm. Amsterdam, Rijksmuseum, inv. no. RP-P-1878-A-1320 (artwork in the public domain)

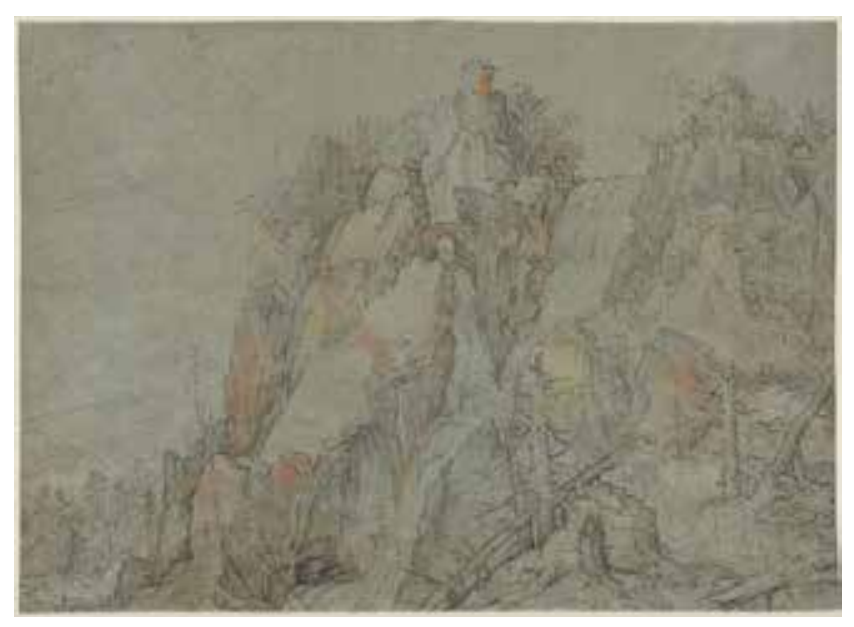

Fig. 5 Roelandt Savery, Mountainous Landscape with Castles and Waterfalls, ca. 1606 , black, ocher, red, and blue chalks, with traces of white heightening on gray-green laid paper, 35.5 x $49.4 \mathrm{~cm}$. Washington, D.C., National Gallery of Art, inv. no. 2011.42 .2 (artwork in the public domain)

12 Savery's taste for landscapes where some of the themes found in the literature of the sublime can be recognized, however, appears to predate this trip. He certainly knew Alpine scenes engraved after the designs of Pieter Bruegel the Elder as well as their derivations, such as the series of engravings by Cornelis Cort (1533-1578) issued by the Antwerp publisher Hieronymus Cock. ${ }^{51}$ Savery's Shipwreck, engraved around 1595 by Aegidius Sadeler II, while Savery was working in Vienna on behalf of the Emperor Rudolf II, shows this influence. Roelandt's brother, Jacob Savery I, who, according to van Mander, had been the apprentice of the Flemish painter and draftsman Hans Bol, equally excelled in this genre, ${ }^{52}$ as did some of his own apprentices, for instance, Willem van Nieulandt II, who together with the painter Paul Bril engraved several fantasy landscapes featuring terrible mountain streams whose devastating power can be measured by the broken bridges portrayed (fig. 4). ${ }^{53}$ Within the same tradition we also find Kerstiaen Keuninck, Hendrick Vroom, and Frederick van Valckenborch, ${ }^{54}$ who, like Savery, seem mostly interested in expressing the wild and dangerous character of the mountains. Savery was also one of the first Dutch landscape painters frequently to represent waterfalls, which he carefully studied from nature and reworked in his workshop (fig. 5). After he returned to the Netherlands, in 1613, he resided in Amsterdam and Utrecht and continued to produce, with the help of his nephew and pupil, Hans Savery II, many imaginary Alpine landscapes, which seem to have played an essential role in the diffusion of this sublime imagery. ${ }^{5}$

13 Allart van Everdingen probably served as Savery's apprentice at Utrecht in the late 1630s, before moving on to Haarlem to work under Molyn. His early Scandinavian mountain scenes are modeled after Savery's early Tyrolian views and certain Savery-like elements became a permanent part of his vocabulary. ${ }^{56}$ Although Arnold Houbraken speaks of Savery'ss taste for "landscapes, and especially for Nordic views, like rocks and waterfalls" (Landschappen, inzonderheid Noordsche gezigten, als Klippen en Watervallen), ${ }^{57}$ he certainly knew that Savery, unlike his pupil, never traveled to the north of Europe. During this same period, landscape painting in Utrecht experienced a real fashion for the sublime that derived, as we can again emphasize, less from a knowledge of ancient sources than from the progressive development of a common sensibility in regard to violent 
natural phenomena that had been nurtured by works of art produced by Netherlandish painters and engravers since Pieter Bruegel the Elder. One of the founding members of the Utrecht Guild of St. Luke in 1611, Adam Willaerts (1577-1664) served as dean of the corporation during the years when van Everdingen toiled in Savery's workshop (1620-22, 1624-31, 1636-37). It is mainly after the arrival of Roelandt Savery in the city (1619) that Willaerts's landscapes, often borrowing some narrative details from biblical iconography, give more generous place to catastrophic marine scenes like storms and shipwrecks but also to wild depictions of rocky and wooded mountains, that he could have seen in the works of his predecessors and his contemporaries. ${ }^{58}$

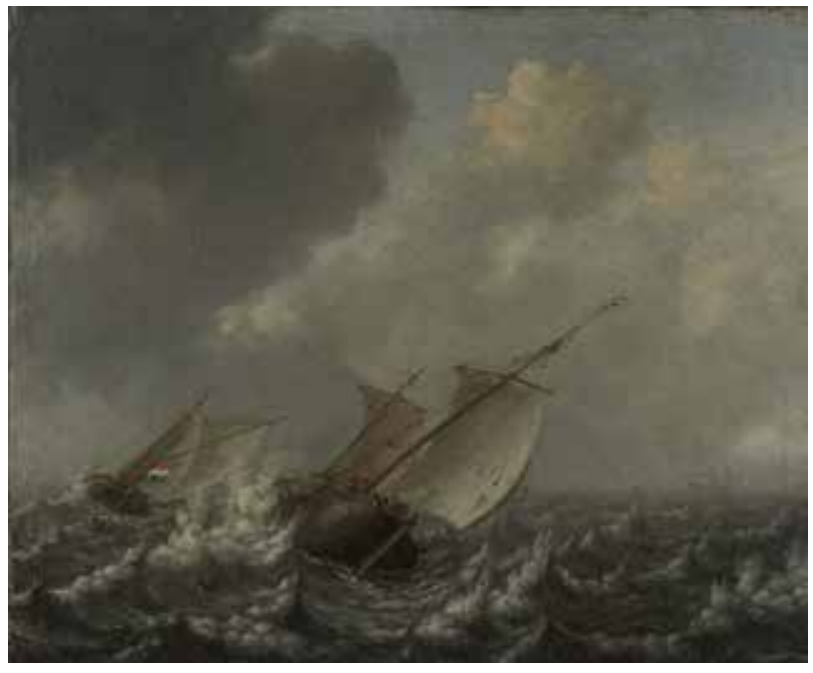

Fig. 6 Jan Porcellis, Vessels on a Choppy Sea, ca. 1620, oil on canvas, $45.2 \times 56.9 \mathrm{~cm}$. New Haven, Conn., Yale University Art Gallery, inv. no. 2012.73.1 (artwork in the public domain)

14 Among the painters who probably played a decisive role in the formation of the eye and the sensitivity of the young van Everdingen was Jan Porcellis, who may have made his apprenticeship in the workshop of Hendrick Vroom, and who studied models largely indebted to the tradition initiated by Pieter Bruegel the Elder (see fig. 2) and taken over by Paul Bril (see fig. 4). Of all the Dutch landscape painters of the first half of the seventeenth century, Porcellis is the one who most scrupulously explored the sublime topoi of the marine landscape, making the representation of stormy seas a real specialty, which he developed in his paintings (fig. 6) as well as in his engravings-Verscheyden stranden en water gesichten, Haarlem, ca. 1620; Icones variarum navium Hollandicarum, Amsterdam, 1627. During his lifetime, he was considered, in the words of historian Samuel Ampzing, as "the greatest ship artist" (de grootste konstenaer in schepen). ${ }^{59}$ Even after his death, his works continued to be perceived and admired specifically for their sublime qualities, as the long, detailed poem that Joachim Oudaan dedicated to one of his "thunderstorms" shows:

The wind rises higher, the sail swells the rounder with it.

Be careful, helmsman, of the sheet, boasting brought many

To submission, who, with their hearts full of pride

Were ashamed to take in a reef when in distress. Here the waves are rough

Sailor and master's guest toil so hard they labor

At the rudder and on the deck in order to break the beating waves on the bows

If one could. The helmsman's pea jacket drowns, 
While a billow that beats on the stem

Leaps backwards and falls in round droplets,

And makes the sailor's hair like the heads of water-dogs.

A cloud comes from above, which,

Driven on and on by a beam wind, begins suddenly

To pour; it splashes on board and pierces so much the more severely

Through the blue sailor's cap, through boots and rain jackets

Soaking to the skin. To which he pays no heed,

But cries (while the wind roars out so that it booms)

The rudder is forced to leeward, the ship is on a low shore,

Push off, apply your strength. Yet a cool fellow usually sits

On the main deck and watches the game

Although wind punishes and rainshowers beat;

Porcellis likewise does not creep into the forecastle,

But considers the storm calmly (in spite of water, rain, hail and thunder)

In order to examine in life this raging element,

Which you engrave in thoughts. ${ }^{60}$

15 One might suggest that this analysis of Porcellis's painting by Oudaan is just a simple personal point of view. Yet the same categories used by Oudaan structure the almost contemporary comments of the Dutch painter Arnold Houbraken who, speaking of Porcellis, writes that he painted natural and skillful boats, sea storms and strands, with charming figures. I have seen some of them representing how fishers drag their fishing nets on rolling waves towards the strand; where again they suffer to transport their load in baskets on their shoulders through the dunes; but his artful pencil especially excelled in the natural representation of his sea storms, where he makes flicker the stormclouds covering the sun and giving the impression of the night during the day as well as the powerful thunder breaking through the gathered clouds on the rocks, the strands and the foaming brine, and that so naturally that the vulgar man could be scared by the waters of the sea. ${ }^{61}$

16 Everything seems to show that, during this era, there existed a true sublime sensitivity, implemented by artists and experienced as such by the audience, even if it is unlikely, again, that teither could have been directly and explicitly aware of the categories they put into play. What we might call a "sublime generation" emerged at the same time as van Everdingen's formation as an artist. It is therefore not surprising that his earliest works are marine paintings, painted in a manner quite close to the handeling of Jan Porcellis. ${ }^{62}$ Van Everdingen probably became a member of the Alkmaar Guild of St. Luke about 1640 when he signed and dated his first picture, the Rough Sea (formerly Montana, collection of Senator Clark). ${ }^{63}$ These early works are also reminiscent of the productions of his contemporaries, like Simon de Vlieger ${ }^{64}$ or Bonaventura Peeters (fig. 7), whose landscapes are also described by Arnold Houbraken in explicitly sublime terms: 


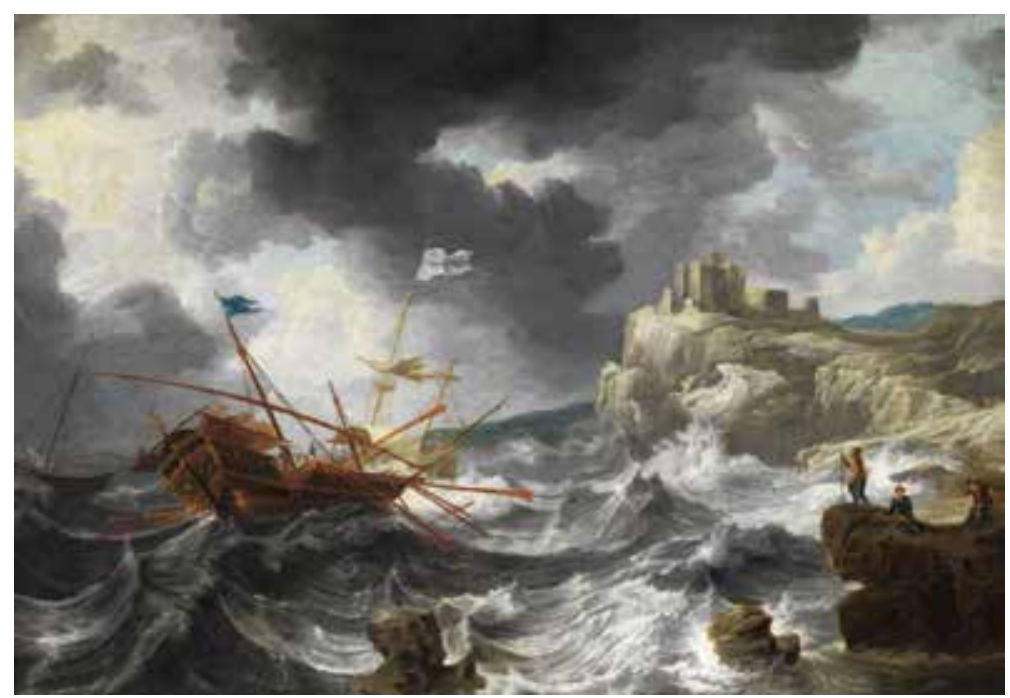

Fig. 7 Bonaventura Peeters, Shipwreck, ca. 1652, oil on canvas, $50 \times 85 \mathrm{~cm}$. Private collection (artwork in the public domain)

Bonaventura Peeters ... painted sea storms and ships in danger of wreck due to all kinds of sad sea disasters. ... He depicted how Aeolus in a wrathful mood presses the clouds with his storm winds from four directions, and squeezes them so that they burst out with a dangerous roar of lightning and thunder, with blow on blow batter the sails, masts, topmasts, and the hull of the sea ships, so that splinters fly about the ears of the sailors, who in this disaster predict with tightened lips their last hours. Then again how Neptune, disturbed by the pride of the sea rocks, stirs up the brine, and from the immeasurable depths, comes ashore against them with his triple staff, spattering the highest peaks with foam; and how the ships fall into those breakers, jerked hither and yon, finally pound themselves to splitting; people and goods are brought into danger of perishing: a crowd of people appears on a single wreck breaking up; while others again seek to save their lives by swimming. Or also how the cast-aways on some crowded beach relate their experiences with burdened shoulders, and beg for assistance, etc. He knew how to represent these and similar sad things so properly in their appearances, and also how to paint air, water, cliffs, and beaches so naturally, that he was judged to be the best in his time in this way of painting. ${ }^{65}$

17 Van Everdingen certainly knew very well the work of Porcellis and Peeters as well as that of their predecessors. After his death, he left to his widow Janneke Brouwers a good fortune as well as a quite important collection of paintings. In the March 3, 1676, issue of the Haarlem Courant, a sale of van Everdingen's collection of paintings was advertised, proposing to sell "all the beautiful landscapes of the painter Allart van Everdingen as well as paintings by other masters." ${ }^{66}$ Later, some of these "other masters" are named-Raphael, Giorgione, Annibale Carracci, Titian, Veronese, Holbein, Savery, Porcellis, Hals, and Rembrandt. ${ }^{6}$

\section{Van Everdingen and the Sublime Tradition of European Landscape}

18 Van Everdingen's pictorial culture was not only visual but also textual. Dutch artistic literature, to which, like most of his colleagues, he undoubtedly had easy access, abounds with examples of landscapes obviously structured by the categories of the sublime. ${ }^{68}$ Therefore, it is also necessary 
to pay attention to the ideas and the arguments on the sublime that in the sixteenth and seventeenth centuries circulated via compilations and intermediate sources, that made extensive use of the texts of Longinus and Lucretius, especially when describing works of ancient and modern art.

One of the first painters to have appeared in such a work is Ambrogio Lorenzetti, whose Shipwreck ${ }^{69}$ had been first admired by Lorenzo Ghiberti:

After the decapitation of the monks there arises a storm, with much hail, flashes of lightning, and thundering earthquakes; it seems as if it were possible to see painted [there] heaven and earth in danger. It seems as if all were trying with much trembling to cover themselves up; the men and the women are pulling their clothes over their heads, and the armed men are holding the shields over their heads. The hailstones are so thick on the shields that they seem actually to bounce on the shields with the extraordinary winds. The trees are seen bending even to the ground as if they were breaking, and each person seems to be fleeing, everyone is seen to be fleeing. The executioner is seen to fall under his horse, which kills him; on account of this many people were baptized. For a painted story it seems to me a marvellous thing. ${ }^{70}$

20 The terms used by Ghiberti are a perfect and complete compilation of the most common themes of the Longinian sublime. The sea and its dangers, metaphorized by marine animals, is particularly responsible for these sublime values:

Much superior to the passages respecting the Battle of the Gods are those which represent the divine nature as it really is-pure and great and undefiled; for example, what is said of Poseidon in a passage fully treated by many before ourselves: "Her far-stretching ridges, her forest-trees, quaked in dismay,/And her peaks, and the Trojans' town, and the ships of Achaia's array,/Beneath his immortal feet, as onward Poseidon strode./Then over the surges he drave: leapt sporting before the God/Sea-beasts that uprose all round from the depths, for their king they knew,/ And for rapture the sea was disparted, and onward the car-steeds flew (Iliad 13.18, at Perseus)." ${ }^{\prime 1}$

21 The storm, with its powerful winds, also plays a central role in this sublime perception of landscape, as Longinus says: "Homer, when describing tempests, picks out the most appalling circumstances." 72 At the end of the seventeenth century, the Dutch painter and theoretician Samuel van Hoogstraten, seeming to be directly under the influence of Lucretius, speaks in very similar terms to his reader: "If you want to represent a storm wind,/Curve the trees, play with the boughs/let the rain fall, let the lightning streak the sky/and the ships sink. But do not make these woes be harmful' (Indien 't u lust een stormwindt te verbeelen,/Zoo buig 't geboomt, en laet de takken speelen,/ Laet regenen, laet vry den blixem slaen,/En masteloos een Schip te gronde gaen:/Dat ongeluk en zal toch niemand schaeden). ${ }^{73}$

22 Ghiberti also evokes the eminently sublime theme of the storm, with lightning and thunder, which brings us to many passages of Longinus's Peri hypsous, when thunder is presented as the ul- 
timate sublime effect: "How transcendent also are the images in the Battle of the Gods: 'Far round wide heaven and Olympus echoed his clarion of thunder' (Iliad 21.388,)." ${ }^{74}$ Van Hoogstraten also advises in his book the painters who want "to make the eye look and wonder" ('t oog doen staeren en verwonderen) to represent "a storm, with lightning and thunder" (een storm, met weerlichten en donderen) but also "a terrible view on the Swiss mountains, dreadful with their crests and their wind and their storms" (een naer gezicht in't Zwitsersche gebergt,/Dat met zijn kruin en wind en onweer tergt) or a waterfall: "Let their white-snow roofs glitter/and the water hurtling in curves and drops" (laet glinsteren zijn wit besneeude huiven,/Daer 't water krom en dronken af komt stuiven). ${ }^{75}$

23 These natural events and these threatening places are associated, in Ghiberti's text as well as in his sublime sources, with a sense of danger that grabs the beholder viewing a sublime landscape. In Homer, the spectacle of the raging sea produces the most powerful and sublime effects: "And far as a man with his eyes through the sea-line haze may discern,/On a cliff as he sitteth and gazeth away oer the wine-dark deep,/So far at a bound do the loud-neighing steeds of the Deathless leap/ (Iliad 5.770)." He makes the vastness of the world the measure of their leap. The sublimity is so overpowering as naturally to prompt the exclamation that if the divine steeds were to leap thus twice in succession they would pass beyond the confines of the world. ${ }^{76}$

24 Van Everdingen obviously never saw Lorenzetti's lost painting. He probably never read the description written by Lorenzo Ghiberti and certainly did not possess the culture and the literary and philosophical references of the Italian sculptor. However, it is likely that Lorenzetti's mythical landscape was not unknown to him. Lorenzetti is quoted and praised by van Mander, and in 1678, Samuel van Hoogstraten speaks of him as "the first to have begun to imitate again the tempest, the rain and the storm, since Apelles has been very famous among the ancients for his paintings which represented Brontes, Astrapes, and Ceraunobolus" (d'eerste, die tempeest, regen, en onweer, wederom heeft beginnen na te bootsen. Waer in Apelles by de ouden, door zijn stukken, die Brontes, Astrapes, en Ceraunobolus genoemt wierden, zeer geroemt is geweest). ${ }^{7}$

25 More generally speaking, it seems that Ghiberti was not the only one author to use sublime notions to describe and praise the catastrophic landscapes of his contemporaries. In a description written between 1455 and 1456 of a lost Storm by Gentile da Fabriano, Bartolomeo Fazio admires in similar terms the horror aroused in the viewer by this picture: "He also painted in the same city [Venice] a whirlwind, ripping trees with their roots and other things like that, the appearance of which is likely to hit the viewer with horror and fear" (Pinxit item in eadem urbe turbine arbores caeteraque id genus radicitus evertentem, cuius est ea facies, ut vel prospicientibus horrorem ac metum incutiat). ${ }^{78}$ As Hanna Gründler has pointed out, Vasari's description of the "catastrophic paintings" of Raphael, Jacopo Palma the Elder, or Giulio Romano-fires, storms, destructions - can be directly linked, thematically and lexically (terribilità), to the Longinian categories (deinotès), which Vasari probably knew through his frequenting of Florentine intellectual circles. ${ }^{79}$ We find in these descriptions many references to sublime topics, like those of the fire or the torrent, which had been frequently used by Longinus and Lucretius. ${ }^{80}$ Van Mander as well as van Hoogstraten also note Palma's "noble shipwreck in an horrible sea-storm, represented with a great attention" (heerlijke Schipstorm een gruwzaem Zee-onweder, met grooten aendacht uitgebeelt), ${ }^{81}$ when referring to shipwrecks painted by Aert van Leyden or Pieter Bruegel the Elder 
(see fig. 2). ${ }^{82}$

26 It is therefore very probable that, when van Mander quotes Pliny to praise Apelles for having "depicted lightning, thunder, and other such things" (maecte blixem, donder in sulcke ander dinghen), or when he encourages the painters to dedicate themselves to the expression of the same effects, he is thinking about these ancient models and the sublime categories on which they are based. But van Mander also tries to make reference to a sublime imagery, both literary and visual, shared by many of its readers, including the less learned:

Let then raging moist waves, whipped us by Aeolus' orders, imitate black thundery skies, monstrously ugly; and let crooked lightning bolts come flashing through the dark air of the tempestuous storm from the hand of the highest of the gods, so that all mortal, soul-bearing beings seem to be afraid of such a governing. ${ }^{83}$

27 These many examples, both visual and literary, of sublime imagery contributed to building what I propose to call here a "sublime sensitivity" This sensitivity, having long since internalized the sublime categories, eventually produced, before the works of art but also at the spectacle of nature, physical and psychological reactions directly tied to the effects Longinus and Lucretius described in the sublime works of art. That is why, for example, the Dutch sailor Jan Huygen van Linschoten described a storm in which he had been involved in sublime words:

The strength and endurance of the storm was a horror for us to hear, who stood on land, how much the worse for those in ships swarming on the sea, so that those twelve ships perished on the coast and cliffs around Tercera alone, and not only on one side or place of the island, but in all corners and places, so that one heard nothing but lamenting, crying, and groaning, and shouting: there is a ship run to pieces on the cliff, and there another, and all the people drowned. ${ }^{84}$

28 Similarly, referring to the storm that passed through North Holland and Overijssel on November 4-5, 1675, Constantijn Huygens writes in a poem: "The thunder, lightning, and storm of winds from all sides/Were horrifying to eyes and ears" (De Donder, Blixem, Storm van winden allerhand/Zijn grouwelick geweest in Oogen en in Ooren). ${ }^{85}$ The actual experience of danger caused these two contemporaries of Allart van Everdingen afterwards to produce a sublime landscape in which they are both actors and beholders. This means, then, that the sublime categories were not only aesthetic. They contributed to building a real and socially shared sensitivity of what we could describe, after Aby Warburg, ${ }^{86}$ as a Pathosformel, centered around the themes of danger and threat, provoked by certain weather natural events, like storms, fires, waterfalls and mountains, which inspired past artists and painters of van Everdingen's generation.

\section{Allart Van Everdingen and the Art of Sublime Autofiction}

29 To enter more deeply into these complex issues, the next step should be to think about the specificity of van Everdingen's landscapes (figs. 8-14) and to wonder how the paintings and engravings differed from their models and the work of other contemporary artists. A painter like Hendrick Dubbels (1621-1707), for example, worked in Amsterdam as a painter of seascapes and winter landscapes during all his life, trying to continue the tradition inaugurated by the seascapes 
of Jan Porcellis; he collaborated with some of the great masters in this genre, including Simon de Vlieger. Nevertheless, his paintings cannot be confused with those of van Everdingen, especially with the works that made the latter famous.

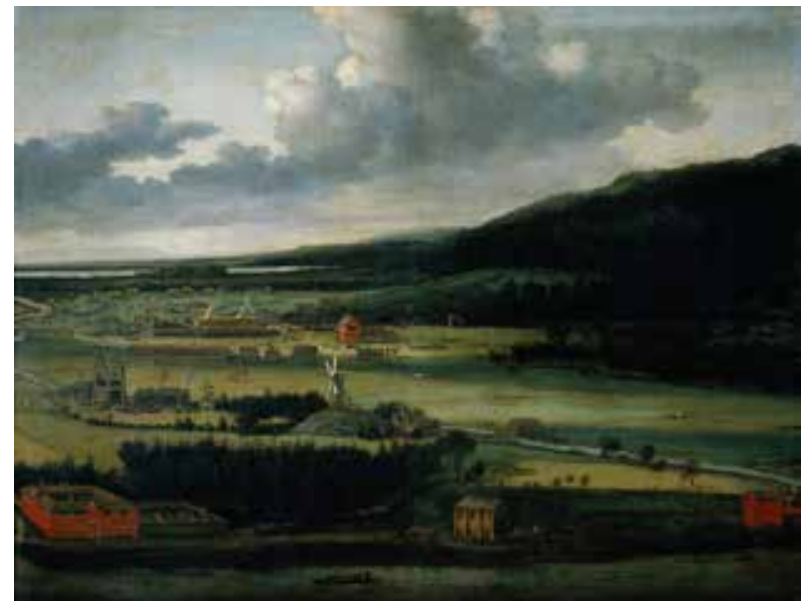

Fig. 8 Allart van Everdingen, Landscape with a Waterfall, ca. 1650-75, oil on canvas, $105 \times 89 \mathrm{~cm}$. Amsterdam, Rijksmuseum, inv. no. SK-A-107 (artwork in the public domain)

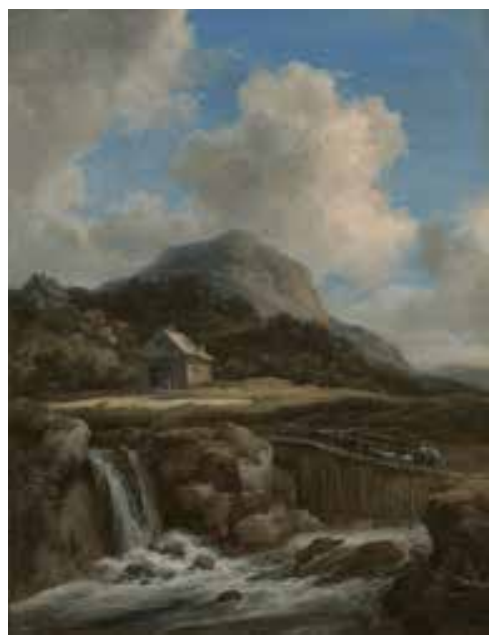

Fig. 10 Allart van Everdingen, Two Draftsmen under a Rock, engraving, $10.1 \times 13.5 \mathrm{~cm}$. Berlin, Staatliche Museen, Kupferstichkabinett (artwork in the public domain)

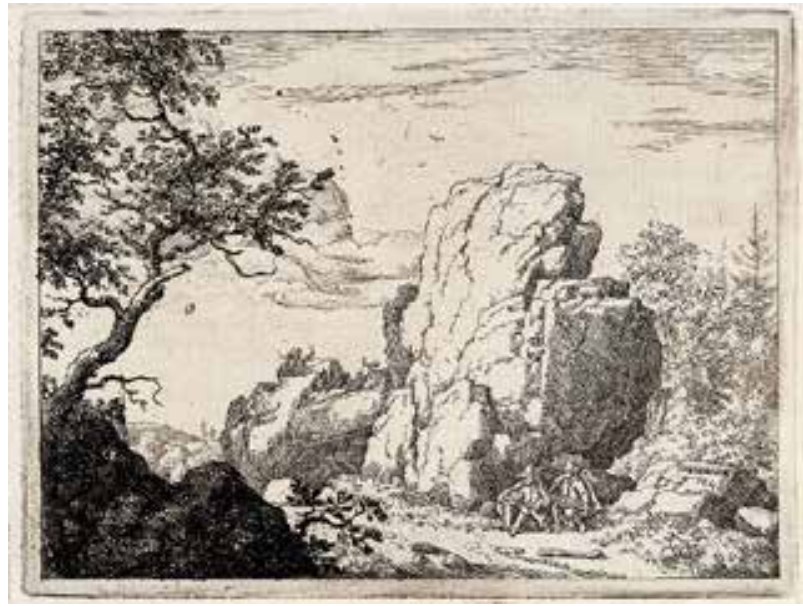

Fig. 9 Allart van Everdingen, Hendrick Trip's Cannon Foundry in Julitabroeck, Södermanland, Sweden, ca. 1650-75, oil on canvas, $192 \times 254.5 \mathrm{~cm}$. Amsterdam, Rijksmuseum, inv. no. SK-A-1510 (artwork in the public domain)

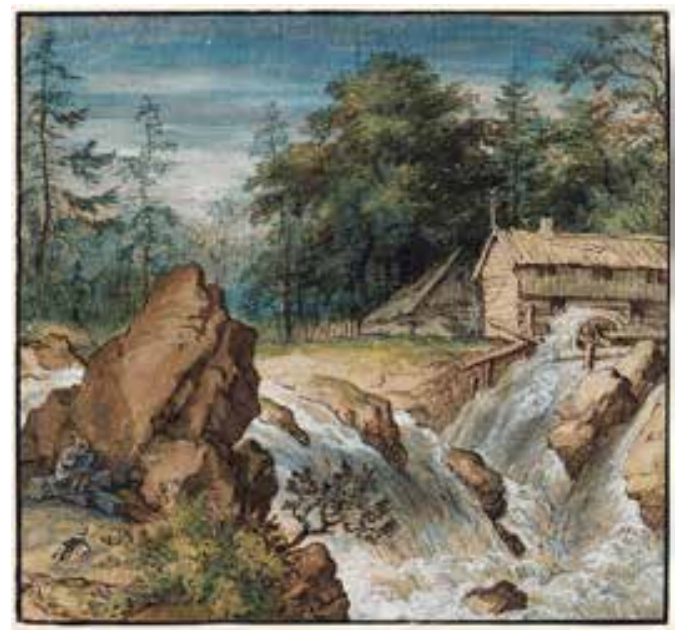

Fig. 11 Allart van Everdingen, A Draftsman near a Waterfall, pencil and brown ink, watercolor, $20.3 \times 21.7 \mathrm{~cm}$. Berlin Staatliche Museen, Kupferstichkabinett (artwork in the public domain)

30 The landscapes that made van Everdingen famous in his own time are his so-called Scandinavian landscapes, painted after he was shipwrecked along the Norwegian coast. According to Arnold Houbraken's testimony, confirmed by several annotated drawings by the artist himself, the painter seems to have been on the eastern coast of Norway and in western Sweden between 1643 and 1644. ${ }^{87}$ During this stay, he probably visited two ports in southern Norway, Risör (then called Österrisör) and Langesund, in the Gothenburg area and the province of Bohusland, up the Göta River north of the city. ${ }^{88} \mathrm{He}$ depicted the small town of Mölndal, just to south of Gothenburg, the Bohus fortress, and Gullöfallet at Trollhättan, in western Sweden, as well as Hendrick Trip's cannon foundry in Julitabroeck, in the Swedish county of Södermanland (see fig. 9). ${ }^{89}$ The most 
stimulating detail of this journey was narrated by Arnold Houbraken:

He [Allart van Everdingen] especially excelled in the painting of Northern landscapes, where by chance he found an opportunity to make drawings after life; because having boarded ship for some place on the Baltic Sea he encountered a dangerous storm, which landed him willing or not on the coast of Norway. He achieved the same natural character in his colored drawings. ${ }^{90}$

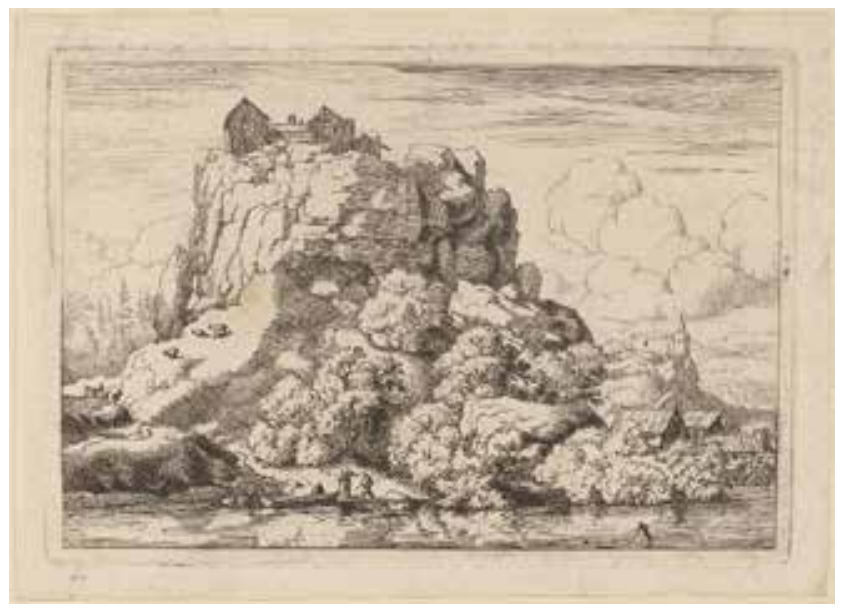

Fig. 12. Allart van Everdingen, River at the Foot of a High Rock, ca. 1645-56, etching, $9.9 \times 14.4 \mathrm{~cm}$. Washington, D.C., National Gallery of Art, inv. no. 1973.15.83 (artwork in the public domain)

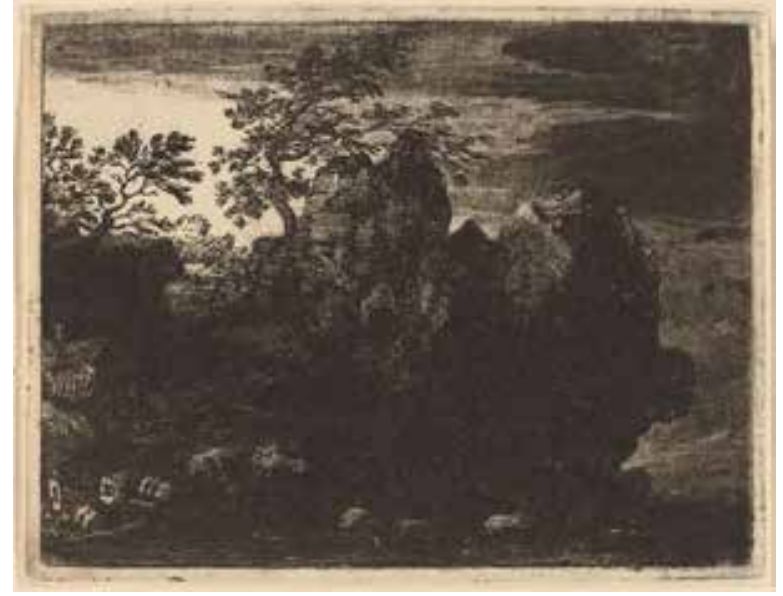

Fig. 13 Allart van Everdingen, Large Rock at the River, ca. 1645-56, etching, $10.4 \times 13.3 \mathrm{~cm}$. Washington, D.C., National Gallery of Art, inv. no. 1973.15 .59 (artwork in the public domain)

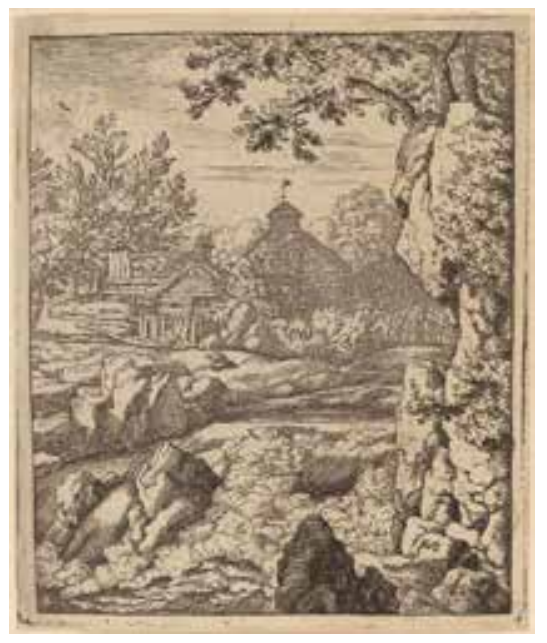

Fig. 14 Allart van Everdingen, Waterfall, ca. 1645-56, etching, $12.9 \times 10.8 \mathrm{~cm}$. Washington, D.C., National Gallery of Art, inv. no. 1973.15.11 (artwork in the public domain)

31 We cannot be sure of the veracity of this information. Yet it is interesting to consider that, for Arnold Houbraken and, probably, for Allart van Everdingen's contemporaries, these northern travels and the landscapes that he painted after his journey are connected with the personal experience of a disastrous and dangerous shipwreck. Real or mythical, this incident in Allart's life is instructive, because it is linked with one of the most frequently quoted topoi in the sublime literature, as we will see later in this paper, and also because the greatest successes in van Everdingen's career are directly connected to this Scandinavian personal experience. According to Alan Chong and John 
Michael Montias, it seems that Allart van Everdingen's landscapes, and especially his waterfalls and northern landscapes, were avidly collected and fetched good prices. ${ }^{91}$ The medium price for landscapes in Amsterdam, in 1650-59 and 1660-69, was respectivelyf. 6.1 and f. 7.07, and van Everdingen's paintings were appraised at an average value of $f .36 .1$, with some very impressive high prices- $f$. 150 in 1657 and $f .100$ in 1670 and 1671. Among the most frequently cited painters in Amsterdam's inventories, Allart van Everdingen was fourth, after Jan van Goyen, Jan Porcellis (see fig. 6) and Pieter de Molijn, yet just ahead of Jacob van Ruisdael. By the late fifties, a number of van Everdingen's contemporaries, especially in Amsterdam, like Jacob van Ruisdael, clearly had adopted his exotic Scandinavian motives (fig. 15). ${ }^{92}$ Around 1660, van Everdingen was engaged in decorating the house of Louis and Hendrick Trip with Scandinavian landscapes, ${ }^{93}$ these two brothers having sizeable business interests in Sweden. In his life devoted to the painter, Houbraken clearly insists, as we already noted, that the most remarkable part of van Everdingen's work is his Scandinavian landscapes.

32 For Houbraken, the most brilliant quality of van Everdingen's landscapes is their naturalness, but he also writes that van Everdingen was "not deficient in intellect" (niet misdeelt van verstant). ${ }^{94}$ Moreover, he focuses on the dangers the painter had to struggle with during his northern journey before being able, back in the Netherlands, to translate these impressions in his own landscapes. If van Everdingen could make convincing sketches after life for his northern paintings, watercolors and engravings, it is because he had shipwrecked on the coast of Norway in a dangerous storm.

33 Van Everdingen appears to have been one of the only seventeenth-century painters to base part of his practice as landscape painter on his own personal experience, a trauma whose sublime nature could be genuinely reflected in his paintings. Perhaps this trauma is mythical. But it does not matter-and it is in any case unverifiable - if van Everdingen's shipwreck actually took place or not. His own story transported him from the (possibly) historical reality to a mythical world in which his life could be included in the great and long tradition of heroic shipwrecks, including those of Ulysses, Theseus, and Saint Paul.

34 The question here is not that of an autobiography but of a self-fashioning, a self-fiction. The originality of van Everdingen's strategy lies in the construction of a personal myth, which was eminently sublime, that he linked to his own history. This guaranteed the authenticity of the images of the Nordic world he presented but also served as a kind of "sublime enhancer" of these same images, since they were surrounded by the aura of an experience actually lived and experienced by their author. Since the sixteenth century, it had become quite commonplace for travelers, to focus on the dangers of their journey, especially in forests, woods, and mountains, which were considered unsafe places. In a letter published for the first time in 1645, James Howell speaks about crossing the Pyrenees and calls those mountains "uncouth huge monstrous excrescences of Nature. ${ }^{95}$ The word uncouth, which is usually pejorative, could instead be related to a kind of sublime sensibility. It recalls Longinus's text, when he speaks, for example, of Euripides who, sometimes, takes the risk of introducing "ideas that are rough-hewn and uncouth and harsh" in order to be sublime. ${ }^{96}$ Van Everdingen's approach was very similar, except that it is not through the words but via an image that he evoked the sublime experience of his shipwreck and the discovery of Scandinavian landscapes. 
35 By inserting in many of his prints and paintings images of artists drawing after nature and physically confronting the gigantic landscapes they are representing (see fig. 10) or even protecting themselves against the dangers they face (see fig. 11), van Everdingen tries both to express the sublime dimension of the territories he represents and to recall his own personal experience, based on a socially shared visual rhetoric.

\section{Van Everdingen and the Categories of the Sublime}

Naturally, van Everdingen also seeks to found the visual grammar of his Scandinavian landscapes upon the models of his predecessors. I will discuss here the techniques and the ideas he used most frequently and show that he is one of the first artists in the history of Dutch seventeenth-century landscape painting to combine them so coherently. Van Everdingen's Scandinavian landscapes are interesting not only because of their iconography, which is directly connected with some of the themes of the sublime literature (the shipwreck, the storm, the waterfall and, more generally, the struggle between man and nature), but also because of the artist's stylistic and aesthetic choices, wherein the issues of a vivid and expressive representation of nature, the infinity of space and the powerful, if not dangerous, effect on the spectator, are quite often evident.

Let us go back for a last time to Arnold Houbraken's text and the words he used to describe the Nordic landscapes of van Everdingen:

One sees landscapes by him, with animals and figures so wonderfully finely painted, and thickly-grown bushes, where the eye sees no end to their depth, and proud foliage so playfully and friskily painted, that it seems to sway against the sky; and waterfalls, and sea storms, where the smashing of the sea water against the hard rock, and the thin spray splashing off it are naturally thinly and spiritedly realized, that the works can pass as masterpieces. ${ }^{97}$

These arguments make it possible to build a triple image. First, the artist thus presented is a universal landscape painter, capable of painting almost all the objects of nature, yet who chooses them according to the effect they can produce on the beholder. The issue is not the illusion or the precision of the representation but, rather, the presence of the image in the fictional and emotional space of the spectator. Houbraken also describes an artist whose landscapes possess singularly evocative, if not synesthesic, qualities, which recreate the impression of movement between the different elements ("a proud foliage so playfully and friskily painted, that it seems to sway against the sky"), or produce the illusion of sound and noise ("waterfalls, and sea storms, where the smashing of the sea water against the hard rock, and the thin spray splashing off it are naturally thinly and spiritedly realized"). Finally, the text conveys the power of an art whose effects on the beholder's eye are considerable: "one sees landscapes by him, with animals and figures so wonderfully finely painted"; "thickly-grown bushes, where the eye sees no end to their depth." This second sentence is even more significative, since the words associated with the theme of looking are linked with those that correspond to feeling and imagination: by seeing no end to the depth of the foliage and bushes, the eye literally and physically feels the sensation of grandeur and infinite space with which it is spontaneously confronted in nature. 
This question of limitless and grand space refers to the very first sublime theme around which van Everdingen articulates his engravings and, above all, his paintings, which often are of large dimensions. In the both the painter sets small figures in opposition to the immensity of mountains, rocks, and forests (see fig.11), according to a technique advised by Longinus: "The author of the Arimaspeia thinks to inspire awe in the following way: 'A marvel exceeding great is this withal to my soul/Men dwell on the water afar from the land, where deep seas roll."' ${ }^{8}$ For van Everdingen, this focalization on different scales is certainly a convenient way of giving a visual translation of the use of exaggeration and hyperbole. These figures of speech are frequently employed in the poetical and rhetorical arsenal of the sublime texts, where the techniques of amplification are very important. Longinus, again:

Amplification (to sum the matter up in a general way) is an aggregation of all the constituent parts and topics of a subject, lending strength to the argument by dwelling upon it, and differing herein from proof that, while the latter demonstrates the matter under investigation. With his vast riches Plato swells, like some sea, into a greatness that expands on every side. ${ }^{99}$

Some the examples given by Longinus focus not only on the themes of infinity and excess but also on ways of characterizing the overwhelming elements - the river or the waterfall out of its bed, the huge rocks threatening the travelers. These very same iconographical topics and stylistic choices can be frequently found in the paintings and the engravings of van Everdingen (see fig. 12). For van Everdingen, the issue of sublime amplification is a double one. On one hand, it is associated with the visual scenery of danger. As Longinus notes, the theme of danger is eminently sublime, because the sublime is eminently dangerous, constantly playing with and against the rules of beauty, which can be contested, even trespassed: "The expression of the sublime is more exposed to danger when it goes its own way without the guidance of knowledge-when it is suffered to be unstable and unballasted-when it is left at the mercy of mere momentum and ignorant audacity." ${ }^{100}$ Describing the visual spectacle of the torrent, the fire, and the maelstrom, Aeschylus writes that his "chant is not of noble strain," as if he wanted to underline the fact that the sublime effect goes beyond, and even destroys, the rules of tragic poetry: "Quell they the oven's far-flung splendour-glow!/Ha, let me but one hearth-abider mark-/One flame-wreath torrent-like I'll whirl on high;/I'll burn the roof, to cinders shrivel it! W-/Nay, now my chant is not of noble strain." 101

41 The sublime amplification can also produce the most powerful, seizing, and stupendous effect on the reader:

Wherefore not even the entire universe suffices for the thought and contemplation within the reach of the human mind, but our imaginations often pass beyond the bounds of space, and if we survey our life on every side and see how much more it everywhere abounds in what is striking, and great, and beautiful, we shall soon discern the purpose of our birth. This is why, by a sort of natural impulse, we admire not the small streams, useful and pellucid though they be, but the Nile, the Danube or the Rhine, and still more the Ocean. Nor do we view the tiny flame of our own kindling (guarded in lasting purity as its light ever is) with greater awe 
than the celestial fires though they are often shrouded in darkness; nor do we deem it a greater marvel than the craters of Etna, whose eruptions throw up stones from its depths and great masses of rock, and at times pour forth rivers of that pure and unmixed subterranean fire. In all such matters we may say that what is useful or necessary men regard as commonplace, while they reserve their admiration for that which is astounding. ${ }^{102}$

From this perspective, the sublime landscape, as it is defined and practiced by van Everdingen, creates a very particular relationship with the beholder, whom the image is specifically and explicitly elaborated for:

Since, however, it is the case that, in discourse, thought and diction are for the most part developed one through the other, come let us proceed to consider any branches of the subject of diction which have so far been neglected. Now it is, no doubt, superfluous to dilate to those who know it well upon the fact that the choice of proper and striking words wonderfully attracts and enthralls the hearer, and that such a choice is the leading ambition of all orators and writers, since it is the direct agency which ensures the presence in writings, as upon the fairest statues, of the perfection of grandeur, beauty, mellowness, dignity, force, power, and any other high qualities there may be, and breathes into dead things a kind of living voice. All this it is, I say, needless to mention, for beautiful words are in very truth the peculiar light of thought. ${ }^{103}$

43 Once again, it is the theme of danger that hyperbole can illustrate most properly. Whereas the beautiful landscape seduces by its charming qualities, the sublime landscape strikes and pleases by placing the reader not in the comfortable and convenient position of a passive and distant beholder but in that of the spectator-actor, indirectly feeling the dangers evoked by the image (see fig. 13):

Our defects usually spring, for the most part, from the same sources as our good points. Hence, while beauties of expression and touches of sublimity, and charming elegancies withal, are favourable to effective composition, yet these very things are the elements and foundation, not only of success, but also of the contrary. Something of the kind is true also of variations and hyperboles and the use of the plural number, and we shall show subsequently the dangers to which these seem severally to be exposed. It is necessary now to seek and to suggest means by which we may avoid the defects that attend the steps of the sublime. ${ }^{104}$

44 Yet the specificity, if not the originality, of van Everdingen's strategy is basing his art upon his personal experiences, by painting landscapes directly inspired by his own stay in Norway and Sweden. This idea that the sublime experience is never better expressed than when it has been really lived by the poet can often be found in the literature on the sublime, here, in Longinus:

When the Sun hands the reins to Phaethon, he [Homer] says 'Thou, driving, trespass not on Libya's sky,/Whose heat, by dews untempered, else shall split/Thy 
car asunder.' And after that, 'Speed onward toward the Pleiads seven thy course./ Thus far the boy heard; then he snatched the reins:/He lashed the flanks of that wing-wafted team;/Loosed rein; and they through folds of cloudland soared./ Hard after on a fiery star his sire/Rode, counselling his son-'Ho! thither drive!/ Hither thy car turn-hither!' Would you not say that the soul of the writer enters the chariot at the same moment as Phaethon and shares in his dangers and in the rapid flight of his steeds? For it could never have conceived such a picture had it not been borne in no less swift career on that journey through the heavens. ${ }^{105}$

But the question of identification in van Everdingen's works is doubled: the painter tied his landscapes to his own experience but he also invited the beholders to an experience by procuration, through the image they could participate in the experience lived by the artist during his Nordic travels. This double movement corresponds quite clearly to the techniques of transport, which, in the realm of sublime practices, plays a central role. Of the three goals of art (docere, delectare, movere), the most sublime goal is, without contest, the one that Longinus calls transport: "The effect of elevated language upon an audience is not persuasion but transport. At every time and in every way imposing speech, with the spell it throws over us, prevails over that which aims at persuasion and gratification." ${ }^{106}$ This transport does not limit itself to the description of the forcible effect of sublime discourses or texts on the hearer or the reader; it also defines another specific effect, marked by the instantaneity and the spontaneity of the sublime action:

Similarly, we see skill in invention, and due order and arrangement of matter, emerging as the hard-won result not of one thing nor of two, but of the whole texture of the composition, whereas Sublimity flashing forth at the right moment scatters everything before it like a thunderbolt, and at once displays the power of the orator in all its plenitude. But enough; for these reflexions, and others like them, you can, I know well, dear Terentianus, yourself suggest from your own experience. $^{107}$

Indeed, many texts describe the sublime style as the best way for an orator to move (movere) his audience. In van Everdingen's landscapes, this crucial issue of transport is not only present in the theme of danger, experienced by the artist during his travels and transcribed by him in his paintings and engravings, it is also expressed, quite systematically, by the presence of little figures (see fig. 14) - hunters, fishermen, or lost travelers-whose main function is to mirror, within the representation itself, the past situation of the author but also the potential situation of the spectator, whom the image addresses emotionally, trying to immerse him in its own fiction. The efficacy of this technique seems to have been highly appreciated: when, some years after the success of van Everdingen's first Nordic landscapes, Jacob van Ruisdael also chooses to paint Scandinavian sceneries, he frequently uses the same procedure (fig. 15).

This first inquiry into the role of the sublime in Allart van Everdingen's world might at first seem quite disappointing or disturbing. Many of the ideas of Longinus and Lucretius presented in this volume were circulated through compilations, anthologies, and polyantheae. ${ }^{108}$ And the ideas expressed in the Peri hypsous and the De natura rerum were frequently disseminated, if not directly quoted, in several sixteenth- and seventeenth-century books, especially in the well-known 


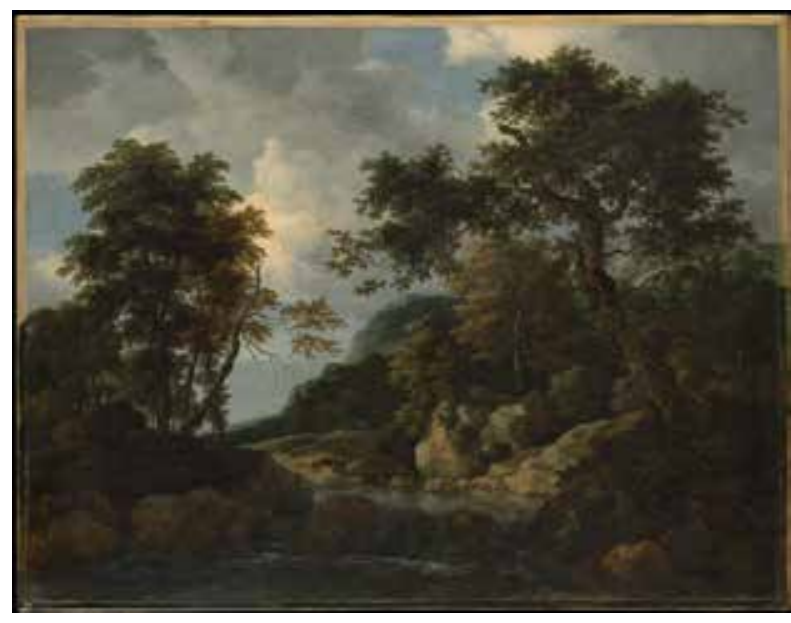

Fig. 15 Jacob van Ruisdael, Mountain Torrent, ca. 1670, oil on canvas, $54 \times 41.9 \mathrm{~cm}$. New York, Metropolitan Museum of Art, inv. no. 25.110.18 (artwork in the public domain)

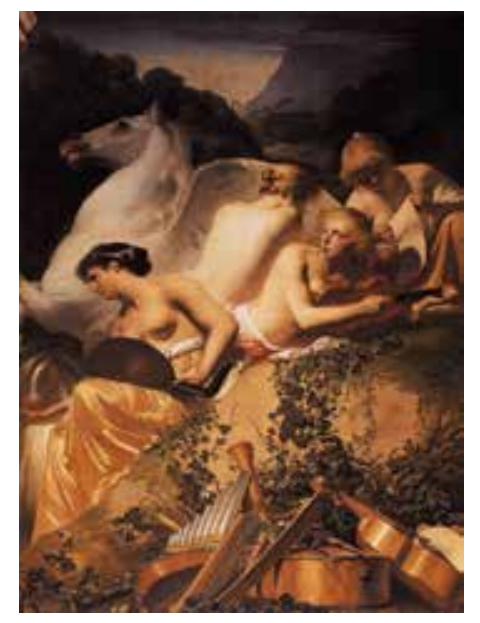

Fig. 16 Jacob van Ruisdael, The Forest Stream, ca. 1660, oil on canvas, $99.7 \times 129.2 \mathrm{~cm}$. New York, Metropolitan Museum of Art, inv. no. 89.15.4 (artwork in the public domain)

treatises of Daniël Heinsius and Gerardus Joannes Vossius. ${ }^{109}$ However, nothing, in what we know of Allart van Everdingen indicates that the painter was able to have direct access to these books. Given his likely linguistic skills-which certainly matched the average of most of his colleagues and contemporaries - it also seems highly unlikely that he could have known the primary sources on sublime theories. Van Everdingen probably never read Longinus, Lucretius, and, a fortiori, Pseudo-Demetrius and Hermogenes in the original. Nevertheless, it seems likely, although difficult to prove, that the prevailing cultural and artistic atmosphere in Haarlem had an impact on Allart van Everdingen's theory and production. No document can attest that Allart actively participated to these activities, although it it problematic to imagine that he remained completely uninterested. We have no proof that Allart was a member of any rederijkerkamer, and many of the theoretical and literary developments in Haarlem painting were linked with history painting and not with landscape painting. Without its having been a direct and evident source, we can still suppose that Allart van Everdingen's artistic milieu in Haarlem provided a rich and stimulating background for the iconographic and formal elaboration of his paintings.

In this context, it is difficult but necessary to resist to any textocentrist interpretation. Surely Allart van Everdingen's sublime culture was built on images more than on texts, whether these images were real (works of art which he saw and studied) or imaginary (missing or fictitious works that he could have known through the artistic literature). Rather than of a sublime culture, moreover, it would be better to speak here of a sublime sensitivity, fueled not only by the arts but also by the everyday life of seventeenth-century Dutch men and women who, faced with the sometimes dangerous spectacle of Nature, often used the categories of sublime rhetoric or literature to describe their life experiences. More than landscapes, Allart van Everdingen's paintings are first-and this remark could possibly be generalized to other Dutch painters of the Golden Age-personal and general experiences translated into images, which would have been all the more powerful as they echoed categories and emotions largely shared by their beholders. 


\section{Acknowledgements}

This article would not have been possible without the critical and friendly help of Stijn Bussels, Caroline van Eck, and Laura Plezier and the support of the European Research Council's starting grant "Elevated Minds"and the Netherlands Institute for Advanced Studies.

Jan Blanc is Professor of Art of the Early Modern Period at the University of Geneva. His research focuses on Flemish, Dutch, and British art and on artistic theory and practice. Among his publications are Peindre et penser la peinture au XVIle siècle (2008); "Rembrandt and the Historical Reconstruction of His 'Conspiracy of Claudius Civilis"' in Myth in History/History in Myth (2009); and Vermeer: La fabrique de la gloire (2014).jan.blanc@unige.ch

\section{List of Illustrations}

Fig. 1 Caesar van Everdingen, Four Muses and Pegasus on Mount Parnassus, ca. 1650, oil on canvas, 340 × $230 \mathrm{~cm}$. The Hague, Huis ten Bosch Palace (artwork in the public domain)

Fig. 2 Johannes and Lucas van Doetechum, after Pieter Bruegel the Elder, Alpine Landscape, ca. 1555-57, etching and engraving, 32.1 x $42.7 \mathrm{~cm}$. Washington, D.C., National Gallery of Art, inv. no. 1964.8.411 (artwork in the public domain)

Fig. 3 Aegidius Sadeler II, after Roelant Savery, Drafhtsman on a Stone before a Bridge, ca. 1609, engraving, 22.5 x 28 cm. Washington, D.C., National Gallery of Art, inv. no. 1943.3.7619 (artwork in the public domain)

Fig. 4 Willem van Nieulandt II, after Paul Bril, A Wooden Bridge over a Mountain Stream, ca. 1594-1635, etching and engraving, 23.5 x $31.1 \mathrm{~cm}$. Amsterdam, Rijksmuseum, inv. no. RP-P1878-A-1320 (artwork in the public domain)

Fig. 5 Roelandt Savery, Mountainous Landscape with Castles and Waterfalls, ca. 1606, black, ocher, red, and blue chalks, with traces of white heightening on gray-green laid paper, $35.5 \times 49.4 \mathrm{~cm}$. Washington, D.C., National Gallery of Art, inv. no. 2011.42.2 (artwork in the public domain)

Fig. 6 Jan Porcellis, Vessels on a Choppy Sea, ca. 1620, oil on canvas, 45.2 x $56.9 \mathrm{~cm}$. New Haven, Conn., Yale University Art Gallery, inv. no. 2012.73.1 (artwork in the public domain)

Fig. 7 Bonaventura Peeters, Shipwreck, ca. 1652, oil on canvas, 50 x $85 \mathrm{~cm}$. Private collection (artwork in the public domain)

Fig. 8 Allart van Everdingen, Landscape with a Waterfall, ca. 1650-75, oil on canvas, 105 x $89 \mathrm{~cm}$. Amsterdam, Rijksmuseum, inv. no. SK-A-107 (artwork in the public domain)

Fig. 9 Allart van Everdingen, Hendrick Trip’s Cannon Foundry in Julitabroeck, Södermanland, Sweden, ca. 1650-75, oil on canvas, 192 x $254.5 \mathrm{~cm}$. Amsterdam, Rijksmuseum, inv. no. SK-A1510 (artwork in the public domain) 
Fig. 10 Allart van Everdingen, Two Draftsmen under a Rock, engraving, 10.1 x $13.5 \mathrm{~cm}$. Berlin, Staatliche Museen, Kupferstichkabinett (artwork in the public domain)

Fig. 11 Allart van Everdingen, A Draftsman near a Waterfall, pencil and brown ink, watercolor, 20.3 x $21.7 \mathrm{~cm}$. Berlin Staatliche Museen, Kupferstichkabinett (artwork in the public domain)

Fig. 12. Allart van Everdingen, River at the Foot of a High Rock, ca. 1645-56, etching, 9.9 x 14.4 cm. Washington, D.C., National Gallery of Art, inv. no. 1973.15.83 (artwork in the public domain)

Fig. 13 Allart van Everdingen, Large Rock at the River, ca. 1645-56, etching, 10.4 x $13.3 \mathrm{~cm}$. Washington, D.C., National Gallery of Art, inv. no. 1973.15 .59 (artwork in the public domain)

Fig. 14 Allart van Everdingen, Waterfall, ca. 1645-56, etching, 12.9 x $10.8 \mathrm{~cm}$. Washington, D.C., National Gallery of Art, inv. no. 1973.15.11 (artwork in the public domain)

Fig. 15 Jacob van Ruisdael, Mountain Torrent, ca. 1670, oil on canvas, 54 x $41.9 \mathrm{~cm}$. New York, Metropolitan Museum of Art, inv. no. 25.110.18 (artwork in the public domain)

Fig. 16 Jacob van Ruisdael, The Forest Stream, ca. 1660, oil on canvas, 99.7 x $129.2 \mathrm{~cm}$. New York, Metropolitan Museum of Art, inv. no. 89.15.4 (artwork in the public domain)

${ }^{1}$ G. Costa, "The Latin Translations of Longinus's Peri hupsous in Renaissance Italy," in Acta Conventus Neo-Latini Bononiensis: Proceedings of the Fourth International Congress of Neo-Latin Studies (Binghamton, N.Y., 1985), 225-38.

${ }^{2}$ Clèlia Nau, Le temps du sublime: Longin et le paysage poussinien (Rennes: Presses Universitaires de Rennes, 2005).

${ }^{3}$ Eugenio Refini, "Longinus and Poetic Imagination in Late Renaissance Literary Theory," in Translations of the Sublime: The Early Modern Reception and Dissemination of Longinus' Peri Hupsous in Rhetoric, the Visual Arts, Architecture and the Theatre, ed. Caroline van Eck et al. (Leiden and Boston: Brill, 2012), 36.

${ }^{4}$ Longinus, On the Sublime, trans. William Rhys Roberts (Cambridge: Cambridge University Press, 1899), chapt. 8, p. 4.

${ }^{5}$ Alice Ingraham Davies, Allart Van Everdingen (New York: Garland Publishing, 1978), 8. ${ }^{6}$ His father was a well-educated man who studied law in Leiden and practiced in The Hague around 1591-92. On May 5, 1598, he is mentioned as a solicitor (taalman), and, in other notarial acts, as a notary (Davies, Allart Van Everdingen, 28; Paul Huys Janssen, Caesar van Everdingen, 1616/17-1678: Monograph and Catalogue Raisonné (Doornspijk: Davaco, 2002), 26-27). It is possible that these employments were not rare in the family. In Edmond aan den Hoef, not far from Alkmaar, a Jan Cornelisz. van Everdingen-maybe the uncle of Allart-is mentioned, living as secretary. Furthermore, Allart's father was not the only notary in the family. One of the painter's brothers, Jan, also had this profession, asking his brothers frequently to appear as witnesses. According to Houbraken, Jan was also an amateur painter: "Jan van Everdingen, also born at 
Alkmaar, practiced the art of still-life painting, more for the love of art than for profit, considering he had another profession, namely, that of an advocate in legal proceedings" (Janssen, Caesar van Everdingen, 33).

${ }^{7}$ Davies, Allart Van Everdingen, 6, 30.

${ }^{8}$ Ibid., 30.

${ }^{9}$ Ibid.

${ }^{10}$ Ibid.

${ }^{11}$ Ibid.

${ }^{12}$ Janssen, Caesar van Everdingen, 95-100.

${ }^{13}$ Hanna Peter-Raupp, Die Ikonographie des Oranjezaal (Hildesheim: G. Olms, 1980); Beatrijs Brenninkmeyer-De Rooij, "Notities betreffende de decoratie van de Oranjezaal in Huis Ten Bosch," Oud-Holland 96, no. 3 (1982): 133-90.

${ }^{14}$ Janssen, Caesar van Everdingen, 100-103.

${ }^{15}$ Ibid., 104-7.

${ }^{16}$ Ibid., 105.

${ }^{17}$ Ibid., $72-73$.

${ }^{18}$ Davies, Allart Van Everdingen, 35.

${ }^{19}$ Ibid.

${ }^{20}$ Maurice Davies, Turner as Professor: The Artist and Linear Perspective (London: Tate Gallery, 1992), 35-36.

${ }^{21}$ Davies, Allart Van Everdingen, 35.

${ }^{22}$ Ibid., 37.

${ }^{23}$ Ibid., 38.

${ }^{24}$ Ibid.

${ }^{25}$ Albert Blankert, ed., Dutch Classicism in Seventeenth-Century Painting (Rotterdam: Museum Boijmans Van Beuningen, 1999), 10.

${ }^{26}$ Janssen, Caesar van Everdingen, 42.

${ }^{27}$ Wilhelm Eduard Drugulin, Allart van Everdingen: Catalogue raisonné de toutes les estampes qui forment son œuvre gravé (Leipzig: W. Drugulin, 1873); Olof Granberg, Allart van Everdingen och hans "norska" Landskap: Det gamla Julita och Wurmbrandts Kanoner (Stockholm: Hæggström, 1902); Georg Göthe, "Har Allart van Everdingen varit i Norge?" Nordisk Tidskrift for Vetenskap, Konst och Industri 26 (1903): 315-19; Davies, Allart Van Everdingen; Alice Ingraham Davies, Allart van Everdingen, 1621-1675, First Painter of Scandinavian Landscape: Catalogue Raisonné of Paintings (Doornspijk: Davaco, 2001); Janssen, Caesar van Everdingen; Nils Büttner, "Noordsche Lantgezigten": Allaert van Everdingen, Jacob van Ruisdael und die neue Sicht auf die Welt in der Kosmographie," in Scientiae et Artes: Die Vermittlung alten und neuen Wissens in Literatur, Kunst und Musik [Wolfenbütteler Arbeiten zur Barockforschung, 38], ed. Barbara Mahlmann-Bauer (Wiesbaden, 2004), 2:1053-75; Alice Ingraham Davies, The Drawings of Allart van Everdingen: A Complete Catalogue, Including the Studies for Reynard the Fox (Doornspijk: Davaco, 2007).

${ }^{28}$ Gert Ueding and Gregor Kalivoda, eds., Historisches Wörterbuch der Rhetorik (Tübingen: Niemeyer, 1992), s.v. "Das Erhabene." For Boileau’s Traité du sublime, see Nicolas Boileau, CEuvres Diverses Du Sieur D***, Avec Le Traité Du Sublime, Ou Du Merveilleux Dans Le Discours, Traduit Du Grec de Longin (Paris, 1674); Longinus, Traité du Sublime, ed. Francis Goyet, trans. Nicolas Boileau (Paris: Librairie Générale Française, 1995).

${ }^{29}$ Jules Brody, Boileau and Longinus (Geneva: Librairie Droz, 1958), 9-13; Costa, “The Latin 
Translations of Longinus's Peri hupsous in Renaissance Italy"; Marc Fumaroli, "Rhétorique d'école et rhétorique adulte: Remarques sur la réception européenne du traité "Du Sublime" au XVIe et au XVIIe siècle," Revue d'Histoire littéraire de la France 86, no. 1 (1986): 35-40; Marc Fumaroli, L'École du silence: Le sentiment des images au XVIIe siècle (Paris: Flammarion, 1994), 126-29. ${ }^{30}$ B. Weinberg, "Translations and Commentaries of Longinus' On the Sublime to 1600, a Bibliography," Modern Philology 47 (1950): 145-51; B. Weinberg, "Ps. Longinus, Dionysius Cassius," in Catalogus Translationum et Commentariorum: Mediaeval and Renaissance Latin Translations and Commentaries, ed. Paul O. Kristeller and F. E. Kranz (Washington, D.C., 1971), 193-98. ${ }^{31}$ Théodore A. Litman, Le sublime en France (1660-1714) (Paris: A. G. Nizet, 1971); Sophie Hache, La langue du ciel: Le sublime en France au XVIIe siècle (Paris: Honoré Champion, 2000); Nau, Le temps du sublime; Emma Gilby, Sublime Worlds: Early Modern French Literature (London: Legenda, 2006).

${ }^{32}$ Pietro Bembo, Prose (Venice, 1524).

${ }^{33}$ Longinus, Liber, de grandi, sive sublimi orationis genere, ed. Francesco Robortello (Bâle, 1554).

${ }^{34}$ Leone Allacci, De erroribus magnorum virorum in dicendo dissertatio rhetorica (Rome, 1635).

We can note that Allacci himself translated Longinus (Rome, Biblioteca Vallicelliana).

${ }^{35}$ Marc Fumaroli, "Crépuscule de l'enthousiasme au XVIIe siècle," in IIIe Congrès International d'Etudes Néolatines (Tours 1976), vol. 11 (Paris, 1980), 1279-1305; Fumaroli, "Rhétorique d'école et rhétorique adulte," n. 2; Nau, Le temps du sublime, 32-38.

${ }^{36}$ B. Weinberg, "Une traduction française du 'Sublime' de Longin vers 1645," Modern Philology 59, no. 3 (1962): 159-203; Longinus, De la sublimité du discours, ed. Emma Gilby and Delphine Denis (Chambéry: L'Act Mem, 2007).

${ }^{37} \mathrm{He}$ was born in Mantua and is described in the family tree as "lord of Punico and Puningo" (heer van Punico ende Puningo). Later, in 1543, he moved to Haarlem, working there as a pawnbroker. After having married Martina Bultens, the daughter of a counselor at The Hague, he became one of the most conspicuous citizens of Haarlem. See Janssen, Caesar van Everdingen, 25. ${ }^{38}$ David Norbrook, Writing the English Republic: Poetry, Rhetoric and Politics, 1627-1660 (Cambridge: Cambridge University Press, 1999); David Norbrook, Poetry and Politics in the English Renaissance (Oxford: Oxford University Press, 2002).

${ }^{39}$ Homer, The Iliad of Homer Prince of Poets, trans. George Chapman (London, 1611); John Milton, Of Education (London, 1644).

${ }^{40}$ Longinus, Peri Hypsous, or Dionysius Longinus of the Height of Eloquence, trans. John Hall (London, 1652); Lydia Hamlett, "The Longinian Sublime, Effect and Affect in 'Baroque' British Visual Culture," in Translations of the Sublime: The Early Modern Reception and Dissemination of Longinus' Peri Hupsous in Rhetoric, the Visual Arts, Architecture and the Theatre, ed. Caroline van Eck et al. (Leiden and Boston: Brill, 2012), xxx.

${ }^{41}$ William Sanderson, Graphice: The Use of the Pen and Pensil: Or, the Most Excellent Art of Painting (London, 1658).

${ }^{42}$ Thomas Blount, The Academie of Eloquence: Containing a Compleat English Rhetorique, Exemplified, with Common-Places, and Formes, Digested into an Easie and Methodical Way to Speak and Write Fluently, According to the Mode of the Present Times, Together with Letters Both Amorous and Moral, upon Emergent Occasions (London, 1653), 47, 65.

${ }^{43}$ J. Porter, "Lucretius and the Sublime," in The Cambridge Companion to Lucretius, ed. S. Gillespie and P. Hardie (Cambridge: Cambridge University Press, 2007), 167-85.

${ }^{44}$ Stephen Jay Greenblatt, De zwenking: Hoe de wereld modern werd [The Swerve: How the World 
Became Modern], trans. Arthur de Smet (Amsterdam: De Bezige Bij, 2012).

${ }^{45}$ Lucretius, Le Poète Lucrèce, latin et françois, trad. Michel de Marolles (Paris: T. Quinet, 1650).

${ }^{46}$ Hendrik Wyermars, Den ingebeelde chaos, en gewaande werels-wording der oude, en hedendaagze wysgeeren, veridelt en weerlegt, byzonder de gevoelens hier omtrent, van T. Lucretius Carus en Dirk Santvoort (Amsterdam, 1710).

${ }^{47}$ Carsten Zelle, Angenehmes Grauen: Literaturhistorische Beiträge zur Ästhetik des Schrecklichen im achtzehnten Jahrhundert (Hamburg: F. Meiner, 1987); Carsten Zelle, Ästhetik des Erhabenen: Von Longin bis Lyotard (Hagen: Fern Universität, 1999); Edmund Burke, Een filosofisch onderzoek naar de oorsprong van onze denkbeelden over het sublieme en het schone [A Philosophical Enquiry into the Origin of Our Ideas of the Sublime and the Beautiful], ed. W. E Krul (Groningen: Historische Uitgeverij, 2004); Christophe Madelein, Jürgen Pieters, and Piet Gerbrandy, eds., Bilderdijk, Kinker and Van Hemert: Als van hooger bestemming en aart (Groningen: Historische Uitgeverij, 2008).

${ }^{48}$ Longinus, Over de verhevenheid, trans. Matthijs Siegenbeek (Leiden: Herdingh, 1811).

${ }^{49}$ Davies, Allart Van Everdingen, 6.

50 "In zijn reysen heeft hy veel ghesichten nae t'leven gheconterfeyt, soo datter gheseyt wort, dat hy in d'Alpes wesende, al die berghen en rotsen had in gheswolghen, en t'huys ghecomen op doecken en Penneelen uytghespogen hadde, soo eyghentlijck con hy te desen en ander deelen de Natuere nae volghen" (van Mander, Het Schilder-Boeck, fol. 233r).

${ }^{51}$ See Simon Novellanus, after Cornelis Cort, Allegorical Landscape with a Shipwreck in a Choppy Sea, ca. 1595, etching, 26.3 x 33.3 cm., London, British Museum, inv. no. 1874,0808.2060.

${ }^{52}$ Larry Silver, Peasant Scenes and Landscapes: The Rise of Pictorial Genres in the Antwerp Art Market (Philadelphia: University of Pennsylvania Press, 2012), 286.

${ }^{53}$ Arnold Houbraken, De groote schouburgh der Nederlantsche konstschilders en schilderessen (1718-1721) (Amsterdam: B. M. Israël, 1976), 1:121-22.

${ }^{54}$ Andor Pigler, "Zum Werk des Frederick van Valckenborch," Oud Holland 77 (1962): 127-29; Giorgio Faggin, "De gebroeders Frederick en Gillis van Valckenborch,” Bulletin van het Museum Boymans-van Beuningen, Rotterdam 14 (1963): 2-16; Margarita Russell, Visions of the Sea: Hendrick C. Vroom and the Origins of Dutch Marine Painting (Leiden: Leiden University Press, 1983); Hans Devisscher, Kerstiaen de Keuninck (1560-1633): De schilderijen met catalogue raisonné (Freren: Luca Verlag, 1987). See, for example, Kerstiaen de Keuninck, A Mountainous Landscape with a Waterfall, ca. 1660, New York, Metropolitan Museum of Art, inv. no. 1983.452.

${ }^{55}$ Filippe de Potter, ed., Savery: Een kunstenaarsfamilie uit Kortrijk (Kortrijk: Koninklijke Geschied- en Oudheidundige Kring van Kortrijk, 2012).

${ }^{56}$ Davies, Allart Van Everdingen, 34.

${ }^{57}$ Houbraken, De groote schouburgh der Nederlantsche konstschilders en schilderessen, 1:56.

${ }^{58}$ Joaneath Ann Spicer, "A Pictorial Vocabulary of Otherness: Roelandt Saverij, Adam Willarts, and the Representation of Foreign Coasts," Nederlands Kunsthistorisch Jaarboek 48 (1998): 22-51; Everhard Korthals Altes, "De ondertekening van Adam Willaerts' Schepen voor een rotsachtige kust," The Rijksmuseum Bulletin 54 (2007): 382-99, 492-93.See, for instance, Adam Willaerts, Shipwreck off a Rocky Coast, 1614, Amsterdam, Rijksmuseum, inv. no. SK-A-1955. On the reception of Willaerts's landscapes, see, for instance, Cornelis de Bie, Het gulden cabinet vande edele vry schilder-const . . (Anvers, 1662), 112; Houbraken, De groote schouburgh der Nederlantsche konstschilders en schilderessen, 1:60 (who speaks of Willaerts just after having presented the life of Roelandt Savery). 
${ }^{59}$ Samuel Ampzing, Beschryvinge ende lot der stad Haerlem in Holland (Haarlem, 1628), 372.

${ }^{60}$ Joachim Oudaan, Joachim Oudaans Poëzy, verdeeld in drie deelen, ed. David Van Hoogstraten (Amsterdam, 1712), 2:115-16; Lawrence Otto Goedde, Tempest and Shipwreck in Dutch and Flemish Art: Convention, Rhetoric, and Interpretation (University Park: Pennsylvania State University Press, 1989), 120. For a comparable reception, see Bie, Het gulden cabinet, 126; Houbraken, De groote schouburgh der Nederlantsche konstschilders en schilderessen, 1:213-14.

${ }^{61}$ Houbraken, De groote schouburgh der Nederlantsche konstschilders en schilderessen, 1:214. Translation by the author.

${ }^{62}$ Davies, Allart Van Everdingen, 34.

${ }^{63}$ Davies, Allart van Everdingen, 1621-1675, 209.

${ }^{64}$ Houbraken, De groote schouburgh der Nederlantsche konstschilders en schilderessen, 2:325.

${ }^{65}$ Ibid., 2:12-13. Translation by the author, based on Goedde, Tempest and Shipwreck in Dutch and Flemish Art, 124-25. For a similar description of Peeters, see Bie, Het gulden cabinet vande edele vry schilder-const., 170.

${ }^{66}$ Davies, Allart Van Everdingen, 41.

${ }^{67}$ Ibid., 42.

${ }^{68}$ Franciscus Junius, De schilder-konst der Oude, begrepen in drie boecken (Middelburg: Zacharias Roman, 1641.), 49-51. On the role of Longinus's treatise in Junius's ideas, see the essay by Thijs Weststeijn in this volume.

${ }^{69}$ Probably The Martyrdom of Saint Peter of Siena, Siena, S. Francesco.

${ }^{70}$ Quoted in Mary D. Edwards, "Ambrogio Lorenzetti and Classical Painting," Florilegium 2 (1980): 150-51.

${ }^{71}$ Longinus, On the Sublime, trans. William Rhys Roberts (Cambridge: Cambridge University Press, 1899), chapt. 9, p. 8.

${ }^{72}$ Ibid., chapt. 10, p. 3.

${ }^{73}$ Samuel van Hoogstraten, Inleyding tot de hooge schoole der schilderkonst (Rotterdam, 1678), 125. Translation by the author; emphasis added.

${ }^{74}$ Longinus, On the Sublime, chapt. 9, p. 6.

${ }^{75}$ Hoogstraten, Inleyding tot de hooge schoole der schilderkonst, 232.

${ }^{76}$ Longinus, On the Sublime, chapt. 9, p. 5.

${ }^{77}$ Hoogstraten, Inleyding tot de hooge schoole der schilderkonst, 125.

${ }^{78}$ Michael Baxandall, Giotto and the Orators: Humanist Observers of Painting in Italy and the Discovery of Pictorial Composition, 1350-1450 (Oxford: Clarendon Press, 1971), 164-65; Michael Baxandall, Giotto et les humanistes: La découverte de la composition en peinture, 1340-1450 (Paris: Éditions du Seuil, 2013), 172.

${ }^{79}$ Hana Gründler, "Orrore, Terrore, Timore: Vasari und das Erhabene," in Translations of the Sublime: The Early Modern Reception and Dissemination of Longinus' Peri Hupsous in Rhetoric, the Visual Arts, Architecture and the Theatre, ed. Caroline van Eck et al. (Leiden and Boston: Brill, 2012), 83-116.

${ }^{80}$ Longinus, On the Sublime, chapt. 9, p. 11; chapt. 32, p. 1.

${ }^{81}$ Palma the Elder and Paris Bordone, Biblioteca dell'Ospedale Civile, Venice.

${ }^{82}$ Hoogstraten, Inleyding tot de hooge schoole der schilderkonst, 125-26.

83 "Laet somtijts dan rasende golven vochtich/Naebootsen beroert door Eolus boden/Zwarte donders wercken leelijck ghedrochtich/En cromme blixems, door een doncker-lochtich/Stormich onweder, comende ghevloden/Wt de handt van den oppersten der Goden,/Dat de sterflijcke 
Siel-draghende dieren/Al schijnen te vreesen door sulck bestieren" (van Mander, Het Schilder-Boeck, Grondt, I, viii, 12-13.

84 "Eenen gheduerighen tempeest ende onweer, dat het een verschricken om hooren was van wy, die op het land stonden, hoe veel te meer die in de schepen op de zee swermden, so dat alleenlijck op de custe ende clippen rontom van het eylandt Tercera bleven over die twaelf schepen, ende dat niet alleenlijck van d'een zyde ofte een plaets van het eylandt, maer rontom op alle hoecken ende plaetsen, soo datmen anders niet en hoorden dan claghen, cryten en kermen, ende segghen: daer is een schip aen de clippe aen stucken geloopen, ende daer een ander, ende alle het volck verdroncken" (Jan Huyghen van Linschoten, Itinerario, voyage ofte schipvaert van Jan Huygen van Linschoten naer Oost ofte Portugaels Indien, 1579-1592, ed. Johan Hendrik Caspar Kern and Heert Terpstra (Le Hague: Martinus Nijhoff, 1955), 3:136.

${ }^{85}$ Constantijn Huygens, De gedichten van Constantijn Huygens, ed. Jacob Adolf Worp (Groningen: Wolters, 1892), 8:130.

${ }^{86}$ Ulrich Port, Pathosformeln: Die Tragödie und die Geschichte exaltierer Affekte (1755-1888) (Munich: W. Fink, 2005); Marcus Andrew Hurttig, Die entfesselte Antike: Aby Warburg und die Geburt der Pathosformel, ed. Thomas Ketelsen (Cologne: W. König, 2012).

${ }^{87}$ Davies, Allart Van Everdingen, 35.

${ }^{88}$ Ibid; Davies, Allart van Everdingen, 1621-1675, 164-65.

${ }^{89}$ Davies, Allart van Everdingen, 1621-1675, 26-27.

90 "Inzonderheid heeft hy uitgemunt in 't schilderen van Noordsche landgezigten, daar hy by zeker toeval gelegentheid toe vont om afteekeningen naar leven te maken; want hy zig naar eenige plaats aan de Oost Zee te scheep begeven hebbende beliep hem eene gevarelyke storm, die hem willig of onwillig niet onbeschadigt op de kust van Noorwegen deed belanden. Den zelven natuurlyken aard heeft hy ook in zyne gekoleurde teekeningen waargenomen" (Houbraken, De groote schouburgh der Nederlantsche konstschilders en schilderessen, 2, 95-96).

${ }^{91}$ Alan Chong, "The Market for Landscape Painting in Seventeenth-Century Holland," in Masters of Seventeenth-Century Dutch Landscape Painting, ed. Peter C. Sutton (Boston: Museum of Fine Arts, 1987), 104-20; John Michael Montias, "Works of Art in Seventeenth-Century Amsterdam: An Analysis of Subjects and Attributions," in Art in History, History in Art: Studies in Seventeenth-Century Dutch Culture, ed. David Freedberg (Santa Monica, Calif.: Getty Center for the History of Art and the Humanities, 1991), 331-72; John Michael Montias, Le marché de l'art aux Pays-Bas, XVe-XVIIe siècles (Paris: Flammarion, 1996), 116.

${ }_{92}$ Davies, Allart Van Everdingen, 38.

${ }_{93}^{3}$ Janssen, Caesar van Everdingen, 50.

${ }^{94}$ Houbraken, De groote schouburgh der Nederlantsche konstschilders en schilderessen, 2, 96.

${ }^{95}$ James Howell, Epistoloe Ho-Eliance. Familiar Letters Domestic and Forren Divided into Sundry Sections, Partly Historicall, Politicall, Philosophicall (Londres, 1655), 1:67.

${ }^{96}$ Longinus, On the Sublime, chapt. 15, p. 5.

97 "Men ziet Landschappen van hem, met Beesjes en Beeldjes zoo wonder fraai geschildert, en digt beplante bosschen, daar het oog door hun diepte geen end aan ziet, en de getrotste meyen zoo spelende en dartel geschildert: dat zy zig tegens de lucht schynen te bewegen: en Watervallen, en Zeestormen, waar in de brandinge van ' $t$ Zeewater tegens de harde rotsen, en de dunne afstuivende sprenkelingen zoo natuurlyk dun, en geestig zyn waargenome dat de stukken voor meesterstukken mogen doorgaan" (Houbraken, De groote schouburgh der Nederlantsche konstschilders en schilderessen, 2:95-96). 
${ }^{98}$ Longinus, On the Sublime, chapt. 10, p. 4.

${ }^{99}$ Ibid., chapt. 12, p. 2.

${ }^{100}$ Ibid., chapt. 2, p. 2.

${ }^{101}$ Ibid., chapt. 3, p. 1.

${ }^{102}$ Ibid., chapt. 35, pp. 3-5.

${ }^{103}$ Ibid., chapt. 30, p. 1.

${ }^{104}$ Ibid., 5.

${ }^{105}$ Ibid., chapt. 25, p. 4. See also Junius, De schilder-konst der Oude (Middelburg: Zacharias Roman, 1641.), 49.

${ }^{106}$ Longinus, On the Sublime, chapt. 1, p. 4.

${ }^{107}$ Ibid., chapt.1, p. 4.

${ }^{108}$ Bernard Beugnot, "Florilèges et Polyantheae: Diffusion et statut du lieu commun à l'époque classique," Études françaises 13, nos. 1-2 (1977): 119-41; Ann Moss, Printed Commonplace-Books and the Structuring of Renaissance Thought (Oxford: Clarendon Press, 1996).

${ }^{109}$ C. S. M. Rademaker, Leven en werk van Gerardus Joannes Vossius (1577-1649) (Hilversum: Verloren, 1999); Daniel Heinsius, De constitutione tragœdioe = La constitution de la tragédie, dite, La poétique d'Heinsius (1611), trans. Anne Duprat (Geneva: Librairie Droz, 2001).

\section{Bibliography}

Allacci, Leone. De erroribus magnorum virorum in dicendo dissertatio rhetorica. Rome, 1635.

Ampzing, Samuel. Beschryvinge Ende Lot Der Stad Haerlem in Holland. Haarlem, 1628.

Baxandall, Michael. Giotto and the Orators: Humanist Observers of Painting in Italy and the Discovery of Pictorial Composition, 1350-1450. Oxford: Clarendon Press, 1971.

-_- Giotto et les humanistes: La découverte de la composition en peinture, 1340-1450. Paris: Éditions du Seuil, 2013.

Bembo, Pietro. Prose. Venice, 1524.

Beugnot, Bernard. "Florilèges et Polyantheae: Diffusion et statut du lieu commun à l'époque classique." Études françaises 13, nos. 1-2 (1977): 119-41.

Bie, Cornelis de. Het gulden cabinet vande edele vry schilder-const . . . Anvers, 1662.

Blankert, Albert, ed. Dutch Classicism in Seventeenth-Century Painting. Rotterdam: Museum Boijmans Van Beuningen, 1999.

Blount, Thomas. The Academie of Eloquence: Containing a Compleat English Rhetorique, Exemplified, with Common-Places, and Formes, Digested into an Easie and Methodical Way to Speak and Write Fluently, According to the Mode of the Present Times, Together with Letters Both Amorous and Moral, upon Emergent Occasions. London, 1653. 
Boileau, Nicolas. Oeuvres Diverses Du Sieur D ${ }^{* * *}$, Avec Le Traité du Sublime, Ou Du Merveilleux DansLe Discours, Traduit Du Grec de Longin. Paris, 1674.

Brenninkmeyer-De Rooij, Beatrijs. "Notities betreffende de decoratie van de Oranjezaal in Huis Ten Bosch.” Oud-Holland 96, no. 3 (1982): 133-90.

Brody, Jules. Boileau and Longinus. Geneva: Librairie Droz, 1958.

Burke, Edmund. Een filosofisch onderzoek naar de oorsprong van onze denkbeelden over het sublieme en het schone [A Philosophical Enquiry into the Origin of Our Ideas of the Sublime and the Beautiful]. Edited by W. E Krul. Groningen: Historische Uitgeverij, 2004.

Büttner, Nils. “Noordsche Lantgezigten': Allaert van Everdingen, Jacob van Ruisdael und die neue Sicht auf die Welt in der Kosmographie." In Scientiae et Artes: Die Vermittlung alten und neuen Wissens in Literatur, Kunst und Musik [Wolfenbütteler Arbeiten zur Barockforschung, 38], edited by Barbara Mahlmann-Bauer, 2:1053-75. Wiesbaden, 2004.

Chong, Alan. “The Market for Landscape Painting in Seventeenth-Century Holland." In Masters of Seventeenth-Century Dutch Landscape Painting, edited by Peter C. Sutton, 104-20. Boston: Museum of Fine Arts, 1987.

Costa, G. “The Latin Translations of Longinus's Peri Hupsous in Renaissance Italy." In Acta Conventus Neo-Latini Bononiensis: Proceedings of the Fourth International Congress of Neo-Latin Studies, 225-38. Binghamton, N.Y., 1985.

Davies, Alice Ingraham. Allart Van Everdingen. New York: Garland Publishing, 1978.

-_- Allart van Everdingen, 1621-1675, First Painter of Scandinavian Landscape: Catalogue Raisonné of Paintings. Doornspijk: Davaco, 2001.

- - . The Drawings of Allart van Everdingen: A Complete Catalogue, Including the Studies for Reynard the Fox. Doornspijk: Davaco, 2007.

Davies, Maurice. Turner as Professor: The Artist and Linear Perspective. London: Tate Gallery, 1992.

Devisscher, Hans. Kerstiaen de Keuninck (1560-1633): De schilderijen met catalogue raisonné. Freren: Luca Verlag, 1987.

Drugulin, Wilhelm Eduard. Allart van Everdingen: Catalogue raisonné de toutes les estampes qui forment son œuvre gravé. Leipzig: W. Drugulin, 1873.

Edwards, Mary D. “Ambrogio Lorenzetti and Classical Painting." Florilegium 2 (1980): 146-60.

Faggin, Giorgio. “De gebroeders Frederick en Gillis van Valckenborch.” Bulletin van het Museum 
Boymans-van Beuningen, Rotterdam 14 (1963): 2-16.

Fumaroli, Marc. "Crépuscule de l'enthousiasme au XVIIe siècle." In IIIe Congrès International d'Etudes Néolatines (Tours 1976), 11:1279-1305. Paris, 1980.

———. L'École du silence: Le sentiment des images au XVIIe siècle. Paris: Flammarion, 1994.

- _ - "Rhétorique d'école et rhétorique adulte: Remarques sur la réception européenne du Traité 'Du Sublime' au XVIe et au XVIIe siècle." Revue d'Histoire Littéraire de La France 86, no. 1 (1986): 33-51.

Gilby, Emma. Sublime Worlds: Early Modern French Literature. London: Legenda, 2006.

Goedde, Lawrence Otto. Tempest and Shipwreck in Dutch and Flemish Art: Convention, Rhetoric, and Interpretation. University Park: Pennsylvania State University Press, 1989.

Göthe, Georg. "Har Allart van Everdingen varit i Norge?” Nordisk Tidskrift for Vetenskap, Konst och Industri 26 (1903): 315-19.

Granberg, Olof. Allart van Everdingen och hans "Norska" Landskap: Det gamla Julita och Wurmbrandts kanoner. Stockholm: Hæggström, 1902.

Greenblatt, Stephen Jay. De zwenking: Hoe de wereld modern werd [The Swerve: How the World Became Modern]. Translated by Arthur de Smet. Amsterdam: De Bezige Bij, 2012.

Gründler, Hana. “Orrore, Terrore, Timore: Vasari und das Erhabene." In Translations of the Sublime: The Early Modern Reception and Dissemination of Longinus' Peri Hupsous in Rhetoric, the Visual Arts, Architecture and the Theatre, edited by Caroline van Eck, Stijn Bussels, Maarten Delbeke, and Jürgen Pieters, 83-116. Leiden and Boston: Brill, 2012.

Hache, Sophie. La langue du ciel: Le sublime en France au XVIIe siècle. Paris: Honoré Champion, 2000.

Hamlett, Lydia. "The Longinian Sublime, Effect and Affect in 'Baroque' British Visual Culture." In Translations of the Sublime: The Early Modern Reception and Dissemination of Longinus' Peri Hupsous in Rhetoric, the Visual Arts, Architecture and the Theatre, edited by

Caroline van Eck, Stijn Bussels, Maarten Delbeke, and Jürgen Pieters, 187-220. Leiden and Boston: Brill, 2012.

Heinsius, Daniel. De constitutione tragœdioe = La constitution de la tragédie, dite La poétique d'Heinsius (1611). Translated by Anne Duprat. Geneva: Librairie Droz, 2001.

Homer. The Iliad of Homer Prince of Poets. Translated by George Chapman. London, 1611.

Hoogstraten, Samuel van. Inleyding tot de hooge schoole der schilderkonst. Rotterdam, 1678. 
Houbraken, Arnold. De groote schouburgh der Nederlantsche konstschilders en schilderessen (1718-1721). 3 vols. Amsterdam: B. M. Israël, 1976.

Howell, James. Epistole Ho-Eliance. Familiar Letters Domestic and Forren Divided into Sundry Sections, Partly Historicall, Politicall, Philosophicall. London, 1655.

Hurttig, Marcus Andrew. Die entfesselte Antike: Aby Warburg und die Geburt der Pathosformel. Edited by Thomas Ketelsen. Cologne: W. König, 2012.

Huygens, Constantijn. De Gedichten van Constantijn Huygens. Edited by Jacob Adolf Worp. 9 vols. Groningen: Wolters, 1892.

Janssen, Paul Huys. Caesar van Everdingen, 1616/17-1678: Monograph and Catalogue Raisonné. Doornspijk: Davaco, 2002.

Junius, Franciscus. De schilder-konst der Oude, begrepen in drie boecken. Middelburg: Zacharias Roman, 1641.

Korthals Altes, Everhard. "De ondertekening van Adam Willaerts' Schepen voor een rotsachtige kust.” Rijksmuseum Bulletin 54 (2007): 382-99, 492-93.

Linschoten, Jan Huyghen van. Itinerario, voyage ofte schipvaert van Jan Huygen van Linschoten naer Oost ofte Portugaels Indien, 1579-1592. Edited by Johan Hendrik Caspar Kern and Heert Terpstra. 3 vols. Le Hague: Martinus Nijhoff, 1955.

Litman, Théodore A. Le sublime en France (1660-1714). Paris: A. G. Nizet, 1971.

Longinus. De la sublimité du discours. Edited by Emma Gilby and Delphine Denis. Chambéry: L'Act Mem, 2007.

—- - Liber, de grandi, sive sublimi orationis genere. Edited by Francesco Robortello. Bâle, 1554.

- - - On the Sublime. Translated by William Rhys Roberts. Cambridge: Cambridge University Press, 1899.

_-_. Over de verhevenheid. Translated by Matthijs Siegenbeek. Leiden: Herdingh, 1811.

- - - Peri Hypsous, or Dionysius Longinus of the Height of Eloquence. Translated by John Hall. London, 1652.

- - - Traité du Sublime. Edited by Francis Goyet. Translated by Nicolas Boileau. Paris: Librairie Générale Française, 1995.

Lucretius. Le Poète Lucrèce, Latin et François. Translated by Michel de Marolles. Paris: T. Quinet, 
1650.

Madelein, Christophe, Jürgen Pieters, and Piet Gerbrandy, eds. Bilderdijk, Kinker and Van Hemert: Als van hooger bestemming en aart. Groningen: Historische Uitgeverij, 2008.

Mander, Karel van. Het Schilder-Boeck. Haarlem, 1604.

Milton, John. Of Education. London, 1644.

Montias, John Michael. Le marché de l'art aux Pays-Bas, XVe-XVIIe siècles. Paris: Flammarion, 1996.

- - . "Works of Art in Seventeenth-Century Amsterdam: An Analysis of Subjects and Attributions." In Art in History, History in Art: Studies in Seventeenth-Century Dutch Culture, edited by David Freedberg, 331-72. Santa Monica, Calif.: Getty Center for the History of Art and the Humanities, 1991.

Moss, Ann. Printed Commonplace-Books and the Structuring of Renaissance Thought. Oxford: Clarendon Press, 1996.

Nau, Clèlia. Le temps du sublime: Longin et le paysage poussinien. Rennes: Presses Universitaires de Rennes, 2005.

Norbrook, David. Poetry and Politics in the English Renaissance. Oxford: Oxford University Press, 2002.

- - Writing the English Republic: Poetry, Rhetoric and Politics, 1627-1660. Cambridge: Cambridge University Press, 1999.

Oudaan, Joachim. Joachim Oudaans Poëzy, verdeeld in drie deelen. Edited by David van Hoogstraten. 4 vols. Amsterdam, 1712.

Peter-Raupp, Hanna. Die Ikonographie des Oranjezaal. Hildesheim: G. Olms, 1980.

Pigler, Andor. “Zum Werk des Frederick van Valckenborch.” Oud Holland 77 (1962): 127-29.

Porter, J. "Lucretius and the Sublime." In The Cambridge Companion to Lucretius, edited by S. Gillespie and P. Hardie, 167-85. Cambridge: Cambridge University Press, 2007.

Port, Ulrich. Pathosformeln: Die Tragödie und die Geschichte exaltierer Affekte (1755-1888). Munich: W. Fink, 2005.

Potter, Filippe de, ed. Savery: Een kunstenaarsfamilie uit Kortrijk. Kortrijk: Koninklijke Geschieden Oudheidundige Kring van Kortrijk, 2012. 
Rademaker, C. S. M. Leven en werk van Gerardus Joannes Vossius (1577-1649). Hilversum: Verloren, 1999.

Refini, Eugenio. "Longinus and Poetic Imagination in Late Renaissance Literary Theory." In Translations of the Sublime: The Early Modern Reception and Dissemination of Longinus' Peri Hupsous in Rhetoric, the Visual Arts, Architecture and the Theatre, edited by Caroline van Eck, Stijn Bussels, Maarten Delbeke, and Jürgen Pieters, 33-53. Leiden and Boston: Brill, 2012.

Russell, Margarita. Visions of the Sea: Hendrick C. Vroom and the Origins of Dutch Marine Painting. Leiden: Leiden University Press, 1983.

Sanderson, William. Graphice: The Use of the Pen and Pensil: Or, the Most Excellent Art of Painting. London, 1658.

Silver, Larry. Peasant Scenes and Landscapes: The Rise of Pictorial Genres in the Antwerp Art Market. Philadelphia: University of Pennsylvania Press, 2012.

Spicer, Joaneath Ann. "A Pictorial Vocabulary of Otherness: Roelandt Saverij, Adam Willarts, and the Representation of Foreign Coasts." Nederlands Kunsthistorisch Jaarboek 48 (1998): 22-51.

Till, Dietmar. Das Doppelte Erhabene: Eine Argumentationsfigur von der Antike bis zum Beginn des 19. Jahrhunderts. Tübingen: M. Niemeyer, 2006. http://dx.doi.org/10.1515/9783110934847

- - _. "The Sublime and the Bible: Ps-Longinus, Protestant Dogmatics, and the 'Sublime Style." In Translations of the Sublime: The Early Modern Reception and Dissemination of Longinus' Peri Hupsous in Rhetoric, the Visual Arts, Architecture and the Theatre, edited by Caroline van Eck, Stijn Bussels, Maarten Delbeke, and Jürgen Pieters, 55-64. Leiden and Boston: Brill, 2012.

Weinberg, B. "Ps. Longinus, Dionysius Cassius." In Catalogus Translationum et Commentariorum: Mediaeval and Renaissance Latin Translations and Commentaries, edited by Paul O. Kristeller and F. E. Kranz, 193-98. Washington, D.C., 1971.

- - _ "Translations and Commentaries of Longinus' On the Sublime to 1600, a Bibliography." Modern Philology 47 (1950): 145-51.

_-_. "Une traduction française du 'Sublime' de Longin Vers 1645.” Modern Philology 59, no. 3 (1962): 159-203.

Wyermars, Hendrik. Den Ingebeelde Chaos, En Gewaande Werels-Wording Der Oude, En Hedendaagze Wysgeeren, Veridelt En Weerlegt, Byzonder de Gevoelens Hier Omtrent, van T. Lucretius Carus En Dirk Santvoort. Amsterdam, 1710.

Zelle, Carsten. Angenehmes Grauen: Literaturhistorische Beiträge zur Ästhetik des Schrecklichen im achtzehnten Jahrhundert. Hamburg: F. Meiner, 1987. 
Zelle, Carsten. Ästhetik des Erhabenen: Von Longin bis Lyotard. Hagen: Fern Universität, 1999.

Recommended Citation:

Jan Blanc, "Sensible Natures: Allart Van Everdingen and the Tradition of Sublime Landscape in Seventeenth-Century Dutch Painting," JHNA 8:2 (Summer 2016), D0l: 10.5092/jhna.2016.8.2.4 